\title{
Article \\ Chemical Characterization of Pope Pius VII Ancient Ecclesiastical Vestment by a Multi-Analytical Approach
}

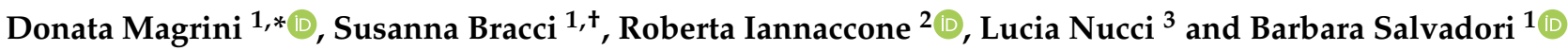 \\ 1 CNR-ISPC, National Research Council, Institute of Heritage Science, 50019 Firenze, Italy; \\ barbara.salvadori@cnr.it \\ 2 Department of Chemistry and Pharmacy, University of Sassari, 07100 Sassari, Italy; riannaccone@uniss.it \\ 3 Textile Conservator, Lucia Nucci Restauri, 50100 Firenze, Italy; nuccilucia@gmail.com \\ * Correspondence: donata.magrini@cnr.it \\ + Dedicated to the memory of our beloved friend and colleague who suddenly passed away during the writing \\ of this article.
}

check for

updates

Citation: Magrini, D.; Bracci, S.; Iannaccone, R.; Nucci, L.; Salvadori, B. Chemical Characterization of Pope Pius VII Ancient Ecclesiastical Vestment by a Multi-Analytical Approach. Heritage 2021, 4, 1616-1638. https:// doi.org/10.3390/heritage4030090

Academic Editors: Nikolaos Laskaris, Maria Kaparou and

Artemios Oikonomou

Received: 22 June 2021

Accepted: 31 July 2021

Published: 6 August 2021

Publisher's Note: MDPI stays neutral with regard to jurisdictional claims in published maps and institutional affiliations.

Copyright: (c) 2021 by the authors. Licensee MDPI, Basel, Switzerland. This article is an open access article distributed under the terms and conditions of the Creative Commons Attribution (CC BY) license (https:// creativecommons.org/licenses/by/ $4.0 /)$.

\begin{abstract}
This paper presents a multi-analytical investigation performed for the study of the ecclesiastical vestment, with insignia, of Pope Pius VII, painted from the end of the 18th up to the beginning of the 19th century, made of five clothing elements: chasuble, stole, maniple, chalice veil and purse. The aim of this research was to assess the conservation state of the silk and painted backgrounds; to define the manufacturing technique of the work; to localize, if present, the underdrawing and any retouching; to identify the pigments and, where possible, the binders used. A diagnostic protocol was developed based on preliminary investigations through multiband imaging techniques known as MBI (visible, ultraviolet-induced visible luminescence (UVL), near-infrared reflected (NIR) and infrared reflected false color (IRRFC) photography). The images acquired with MBI techniques ensured a more specific choice of spots to be analyzed directly in situ by non-invasive techniques. In particular, portable digital optical microscopy and X-ray fluorescence (XRF) were performed. Two fragments detached from the chasuble were also analyzed by microFT-IR, microRaman, scanning electron microscopy (SEM-EDS) and gas chromatography/mass spectrometry (GC-MS). Application of the multi-analytical protocol enabled the materials used to be characterized and helped to define the peculiar execution technique used. The presence of an underdrawing made with a carbon pencil was highlighted by MBI. Red lakes, iron-based pigments and copper-based pigments have been identified on the painting palette, applied with arabic gum as a binder.
\end{abstract}

Keywords: liturgical vestment; chemical characterization; MBI; XRF; microFT-IR; microRaman; SEM-EDS; GC-MS

\section{Introduction}

Several articles describe the characterization of ancient liturgical textiles, their manufacturing process and dyeing techniques [1-13]. These studies are mainly devoted to the characterization of the materials and are generally performed by micro-invasive analytical techniques [8-10,14]. This approach allows the identification of yarn types and the procedure used for preparation, both strictly related to the historical period. Despite the great interest in this kind of artifact, not many works are based on the application of non-invasive protocols [15-21].

Ancient liturgical vestments are very often unique artworks; although several microinvasive techniques are available to investigate these objects, non-invasive methods should always be preferred. In this way, the objects can survive and be left intact for future generations. The non-invasive approach allows the examination of a virtually unlimited number of measurements together with the possibility of performing the analysis in situ, avoiding excessive handling of the object, in particular for very fragile artifacts. 
The liturgical set under study, shown in Figure 1, belongs to a descendent of Pope Pius VII, count Gregorio d'Ottaviano Chiaramonti. The set is made up of five clothing elements: chasuble, stole, maniple, chalice veil and purse. It is a rare example of a chasuble and its accessories made in the eleven years from the end of the 18th up to the beginning of the 19th century, after the death of Pius VII [22].

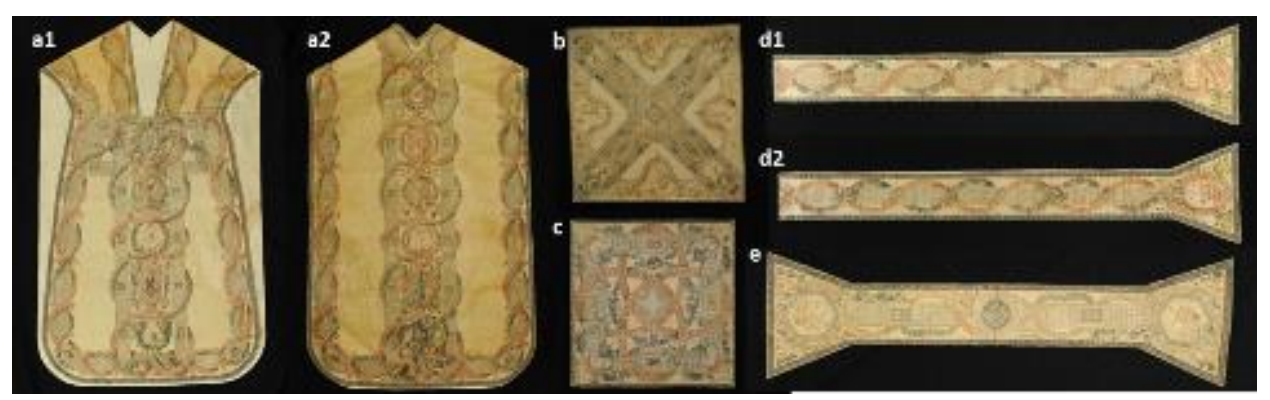

Figure 1. Liturgical vestments analyzed (1795 e il 1806): (a1) recto of the chasuble; (a2) verso of the chasuble; (b) purse; (c) chalice veil; (d1,d2) stole; (e) maniple. Credits Lucia Nucci.

The neoclassic-style decoration, painted on pure silk ermesine, was created by the priest and architect Saverio Caselli, as documented by the signature on each textile element. A similar set of vestments made by Caselli belongs to Victoria and Albert Museum collections, but has not yet been analyzed [23]. The decoration of the five handicrafts is similar, but not, however, identical in all the pieces. It consists of very refined geometric patterns, organized around a Greek-style freeze with sepia, grey and green tones, and inserted squares in which flowered garlands and ribbons of okra gallons are interwoven, reducing the rigidity of the freeze. These three components are connected with grey elements mimicking sculpted figures. The composition of vegetal garlands varies in the different clothing elements, sometimes as a simple laurel motif or with the addition of flowers, vine leaves, wheat sheaves, ivy shoots, pomegranate branches or roses. Each element has a different symbolic meaning. The technique used is a preliminary drawing, underlined with pastel toned watercolors, with grey, pink, golden yellow and faded green predominating. This type of decoration is extremely peculiar for ecclesiastical clothes dated to this period.

A detailed description of the iconography, state of conservation and the conservative intervention is reported in Appendix A.

\section{Materials and Methods}

A diagnostic procedure was developed in the conservation lab starting from a preliminary in situ survey by portable optical microscopy coupled with photographic multiband imaging MBI (VIS, UVL, NIR, IRRFC) to provide a first recognition of the state of conservation of the unpainted and painted silk textiles and to characterize the materials used and their distribution. Further punctual analyses were performed by means of X-ray fluorescence (XRF). Two fragments detached from the chasuble were also analyzed in the laboratory by microFT-IR, microRaman, scanning electron microscopy coupled with energy dispersive X-ray spectrometry (SEM-EDS) and gas chromatography/mass spectrometry (GC-MS) in order to corroborate and complement the results of the non-invasive technique.

\subsection{In Situ Analytical Methods}

For the multiband photographic techniques, two digital cameras were used: a Canon EOS 7D (18 Mpixel, APS-C sensor $223 \times 15 \mathrm{~mm})$ and a modified Canon EOS 400D (10.10 Mpixel, APS-C sensor $223 \times 15 \mathrm{~mm}$ ) without the internal ICF/AA filters. The Canon EOS 7D was used for visible reflected (VIS) and ultraviolet-induced visible luminescence (UVL), taking advantage of the internal filter already designed to cut UV/IR stray radiation, while the Canon EOS 400D was used for NIR photography. Both cameras were equipped with a Canon EF-S $28 \mathrm{~mm}$ f/2.8 lens. As sources of radiation, two Quantum T5D-R flashes were 
used. Both flashes were equipped with a QF80 Qflash UV/IR Wave Reflector with a filter holder.

A combination of filters applied on flashes and the lens provides the proper output and input wavelength band for each technique. The combinations of filters used for this paper are summarized in Table 1.

Table 1. Combination of filters and camera used per MBI.

\begin{tabular}{cccc}
\hline Technique & Camera & Filters on Flashes & Filter on Camera \\
\hline UVL & CANON EOS 7D & B+W 403 UV black & B+W 468 UV /IR cut \\
VIS & CANON EOS 7D & B+W 468 UV / IR cut & B+W 468 UV /IR cut \\
NIR & CANON EOS 400D & B+W 093 IR & B+W 093 IR \\
\hline
\end{tabular}

In order to provide calibrated and reproducible images, a Colorchecker (X-Rite ColorChecker Passport Photo) and a Spectralon ${ }^{\circledR}$ Diffuse Reflectance target (Labsphere) were used at the beginning of the analysis for each wavelength used [24]. Using a graphic program, visible images and near-infrared images were combined to obtain infrared reflected false color (IRRFC) images [25].

All the images were acquired in RAW format to entirely preserve the recorded information and minimize the internal software elaboration. The output images were converted in TIFF format with $2413 \times 3619$ pixels resolution at 8-bit.

X-ray fluorescence spectra [26,27] were collected by a hand-held Bruker Tracer III-SD spectrometer ( $\mathrm{p}-\mathrm{XRF}$ ), equipped with rhodium anode, palladium slits and SDD detector (FWHM < $145 \mathrm{eV}$ at 100.000 cps for $5.9 \mathrm{keV} \mathrm{Mn} \mathrm{K \alpha}$ ). Due to the instrumental presence of $\mathrm{Rh}$ and $\mathrm{Pd}$, the lines of these elements are always detected in the collected spectra. The spectra were acquired for $60 \mathrm{~s}$. with the following working parameters: $40 \mathrm{kV}, 12 \mu \mathrm{A}$. The analyzed area was $3 \times 4 \mathrm{~mm}$. The instrument with this configuration can collect X-ray emissions of elements with atomic numbers higher than sulfur.

The documentation of measured areas and details of the surfaces was performed with a portable optical microscope, mod. Scalar DG-2A with a 25-200× optical zoom. All the photos were acquired at $25 \times$ of magnification (area of $13 \times 8 \mathrm{~mm}$ ).

\subsection{Laboratory Analyses}

It was also possible to analyze two fragments detached from the chasuble. In the laboratory, micro-invasive, non-destructive or micro-destructive techniques were used to integrate the information obtained in situ. At the end of the analyses, the unaltered fragments were returned to the restorer who provided the relocation.

The detached fragments were observed under the optical microscope in visible and UV reflected light and then analyzed by microFT-IR, microRaman and scanning electron microscopy.

MicroFT-IR spectra were collected with an FT-IR spectrometer Agilent Technologies Cary 660 coupled with a Cary 620 Microscope, equipped with an MCT detector. All spectra were acquired in ATR mode in the $4000-400 \mathrm{~cm}^{-1}$ range with germanium crystal, collecting 64 scans, with a resolution of $4 \mathrm{~cm}^{-1}$. Spectra were processed using Agilent Resolutions Pro software, allowing for the characterization of support inks and the binder [28-31].

Red and black pigments on the fragments were analyzed at room temperature with a microRaman single-grating RM2000 Renishaw spectrometer equipped with a Peltiercooled charge-coupled device detector. The Raman excitation was provided by a nearinfrared diode laser operating at $785 \mathrm{~nm}$ and an argon laser operating at $514.5 \mathrm{~nm}$. A $100 \times$ microscope objective was employed to focus the laser beam and collect the scattered light, providing a $1 \mu \mathrm{m}$ diameter laser spot. The spectra were recorded with a laser power of approximately $2 \mathrm{~mW}$ in order to avoid damage to the sample and optimize the signal/background ratio. Spectra were recorded in steps of $1.6 \mathrm{~cm}^{-1}$ with an acquisition time of $30 \mathrm{~s}$. The instrumental resolution, evaluated as the full width at half-maximum (FWHM) of an emission line of a He-Ne lamp, was $7 \mathrm{~cm}^{-1}[20,32,33]$. 
Backscattered electron (BSE) scanning electron microscope (SEM) images were collected from several areas of two fragments. The instrument is equipped with a low vacuum chamber which does not require any sample's treatment. The fragments were indeed placed on the carbon stub and directly inserted into the chamber. Energy-dispersive X-ray spectroscopy (EDS) was used to obtain semi-quantitative elemental analysis and morphological images of the investigated areas. The images and spectra were acquired with an ESEM Quanta200 (Environmental Scanning Electron Microscopy) FEI/Philips Electron Optics. The measurements were taken in a low vacuum (1 Torr) using an accelerating voltage of $25 \mathrm{kV}$ and a working distance of $10 \mathrm{~mm}$.

From the fragments provided, two micro-samples were taken and analyzed by gas chromatography with the mass spectrometric detector (GC/MS) to verify the presence of organic materials used as a pictorial binder. For this purpose, a 6890N GC System gas chromatograph (Agilent Technologies) was used, equipped with PTV injector in splitless mode, coupled with a 5973 mass selective detector (Agilent Technologies) single golden quadrupole mass spectrometer. The gas chromatographic separation was operated on an HP-5MS fused silica capillary column. The GC/MS parameters for the analysis of the different fractions are reported elsewhere [34].

\section{Results and Discussion}

\subsection{Multiband Imaging (MBI)}

As reported in the literature, multispectral images applied to historical textiles can highlight the presence of interesting features, such as the weaving technique [24,35-37].

In this case, near-infrared reflected (NIR) images highlighted the presence of a faint underdrawing used as a guide for the decoration in several areas. An example of this pictorial technique is clearly visible by comparing the images reported in Figure 2. In the infrared reflected image, an almost straight line appears in correspondence to the butterfly wing in order to outline the edge between the Greek meanders decoration and the background curtain.

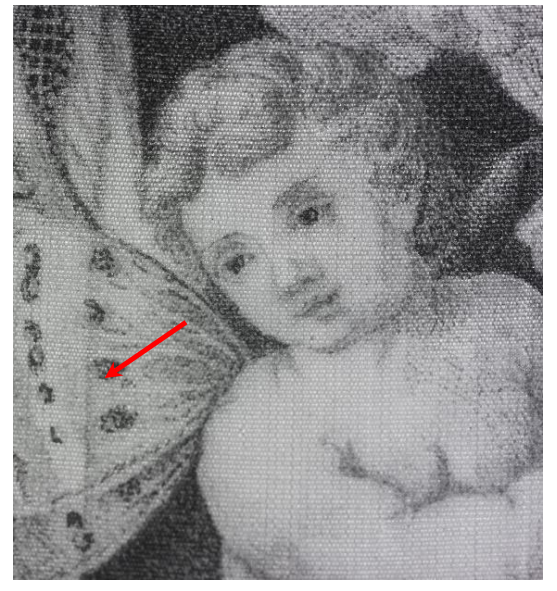

(a)

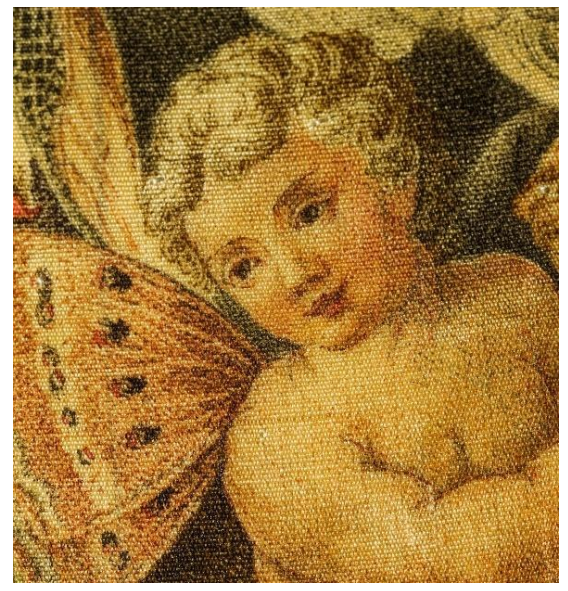

(b)

Figure 2. Detail on the chasuble of a cupid: (a) near-infrared image; (b) visible image.

Drawings as a guide for the painting are also visible in the areas with geometrical decoration. Some of these lines are very thin and also barely visible in the NIR image, while some areas show the presence of marked lines that are also visible with close observation (Figure 3b). 


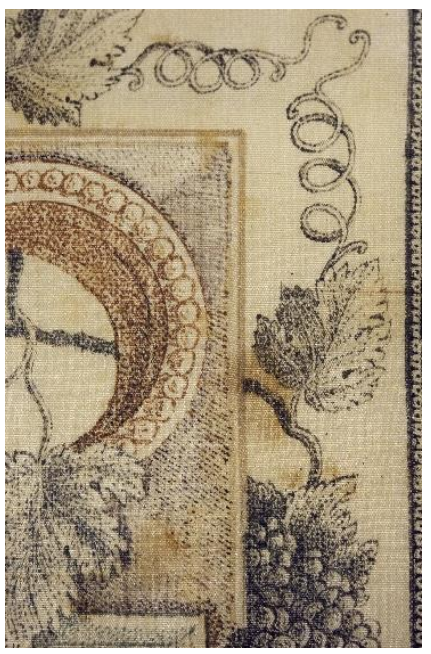

(a)

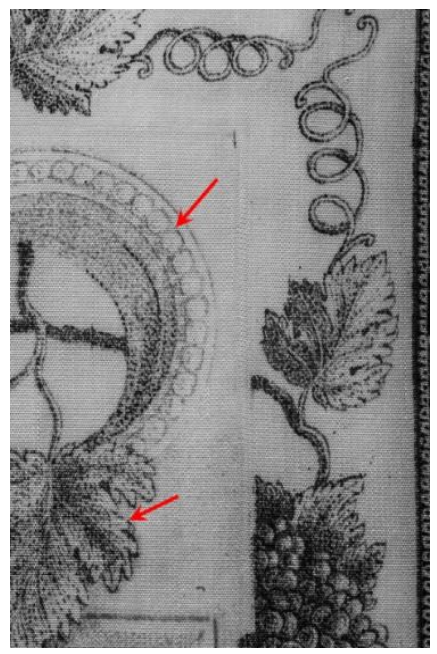

(b)

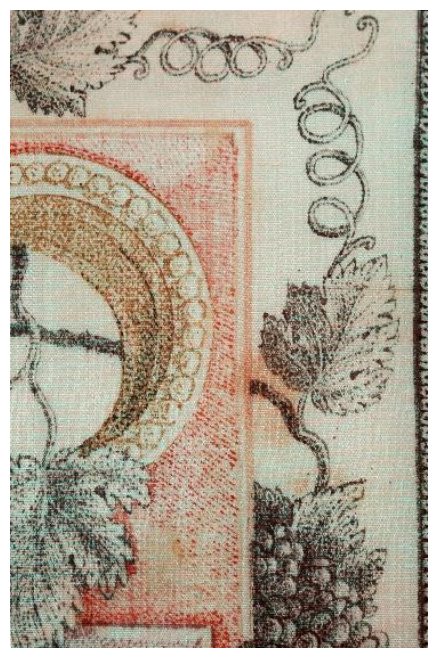

(c)

Figure 3. Detail of the decoration on the purse: (a) VIS image; (b) detail of geometrical guideline; (c) IRRFC image.

Drawings with dark paints compared in NIR and IRRFC images show different behavior. In Figure $3 b$, hatching in the background appears transparent in the NIR region, while the ink used for leaves absorbs the IR radiation, appearing as black. This suggests that the dark areas were painted using at least two types of pigments: one based on carbon black, which absorbs the infrared radiation, and another on iron-gall ink, transparent to near-infrared $[38,39]$.

The use of the IRRFC technique widely highlights these differences among pigments and can be useful for orienting measuring areas for spot analyses [25].

Observing images in visible light, the decoration in Figure 3a appears to be painted with two different materials (black and different shades of brown), while the IRRFC image highlights the use of at least three different paint materials, appearing as red, dull orange and black. As already discussed, the differences between the two dark pigments appear even more enhanced than the NIR image; likewise, the oculus shows the presence of a tannin-based pigment to draw architectural elements and carbon-based pigments to build the shadows.

Analysis of the ultraviolet-induced visible luminescence (UVL) images shows the characteristic blue luminescence of proteinaceous materials [19] and, in some areas, the presence of residual organic material and stains absorbed on the fibers with a yellow luminescence (Figure 4). In some areas corresponding to decorations with a pink/light red color, the images in UVL show a light pink emission. This type of fluorescence can be associated with madder $[19,40,41]$.

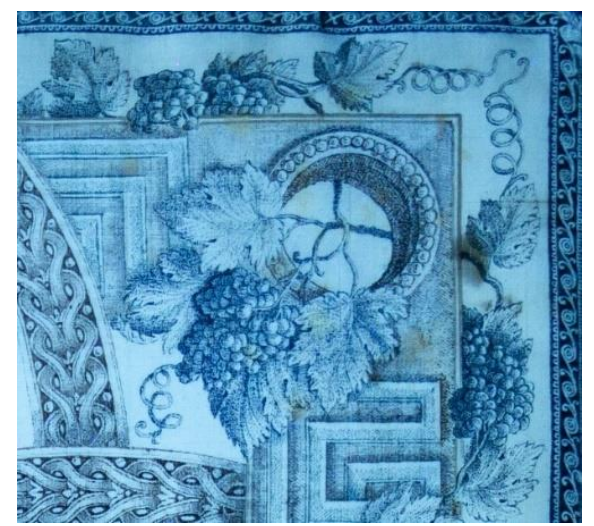

Figure 4. UVL detail of the purse. 
The documentation performed through the portable microscope was addressed to study the conservation status of the textile $[42,43]$ and document the details of the pictorial decoration. Some details of the iconography and decorations are given in Figure 5.
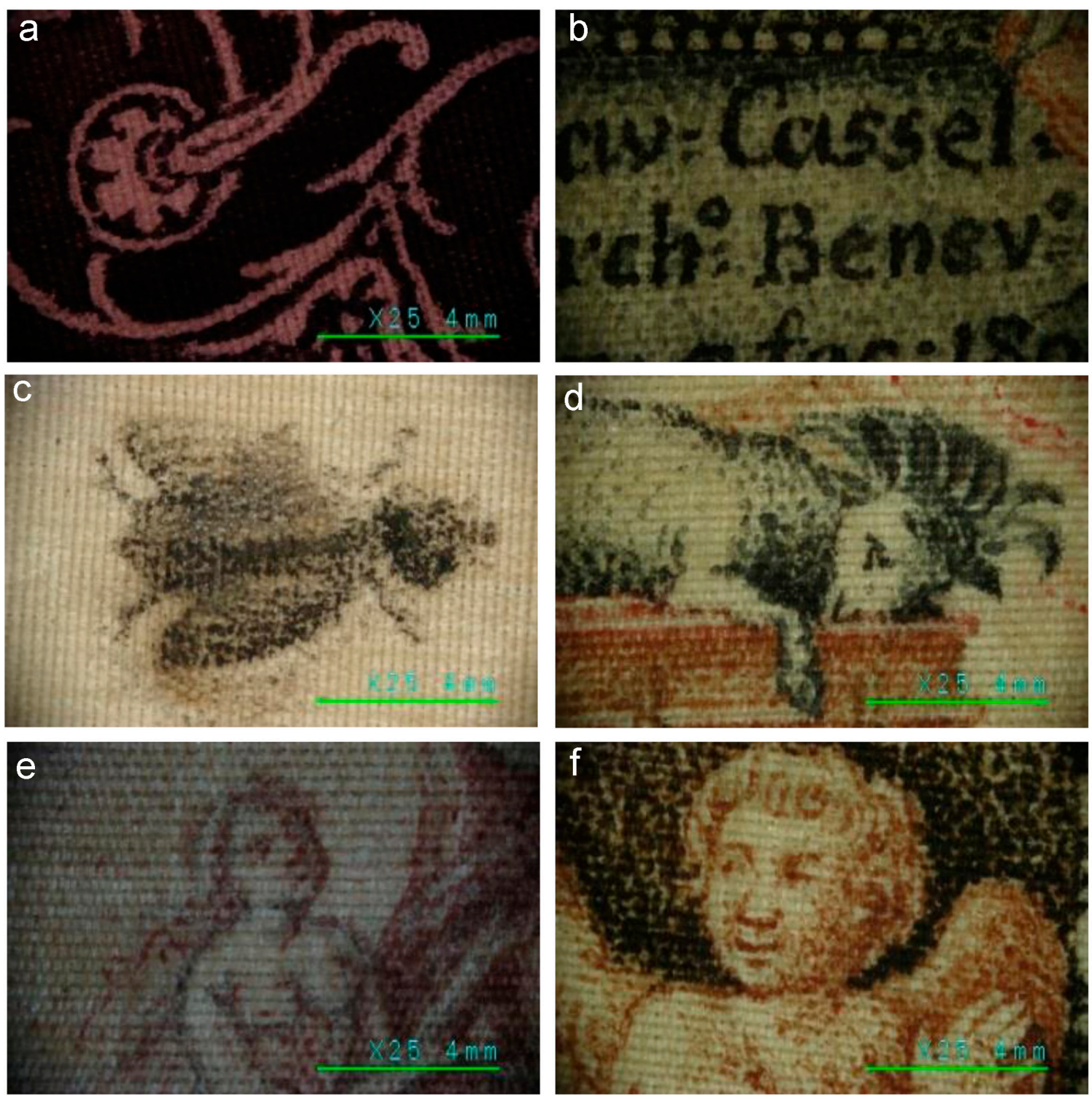

Figure 5. Details of the surfaces acquired through the digital portable microscope: (a) decoration on the maniple; (b) text from the recto of the chasuble; (c) fly from the recto of the chasuble; (d) horse detail from the verso of the chasuble; (e) Eve representation from the verso of the chasuble; (f) Cherubin from the verso of the chasuble.

The acquisitions were also made on the same spot location as that analyzed by XRF, providing detailed documentation of the investigated areas.

\subsection{XRF Elemental Analysis}

The X-ray fluorescence spectra acquired on the elements of the ecclesiastical set are very similar and do not present any key element for identification of the pigments used, except for a few points where $\mathrm{Cu}$ and Fe are revealed. Figure 6 compares the XRF spectra of two spot measurements on the chasuble: one on the unpainted silk and the other on the shadow of the red garland. XRF elemental analysis, apart from detecting the same elements found in the silk support, shows the presence of high counts of iron on the red decoration, suggesting the presence of an iron-based pigment. 


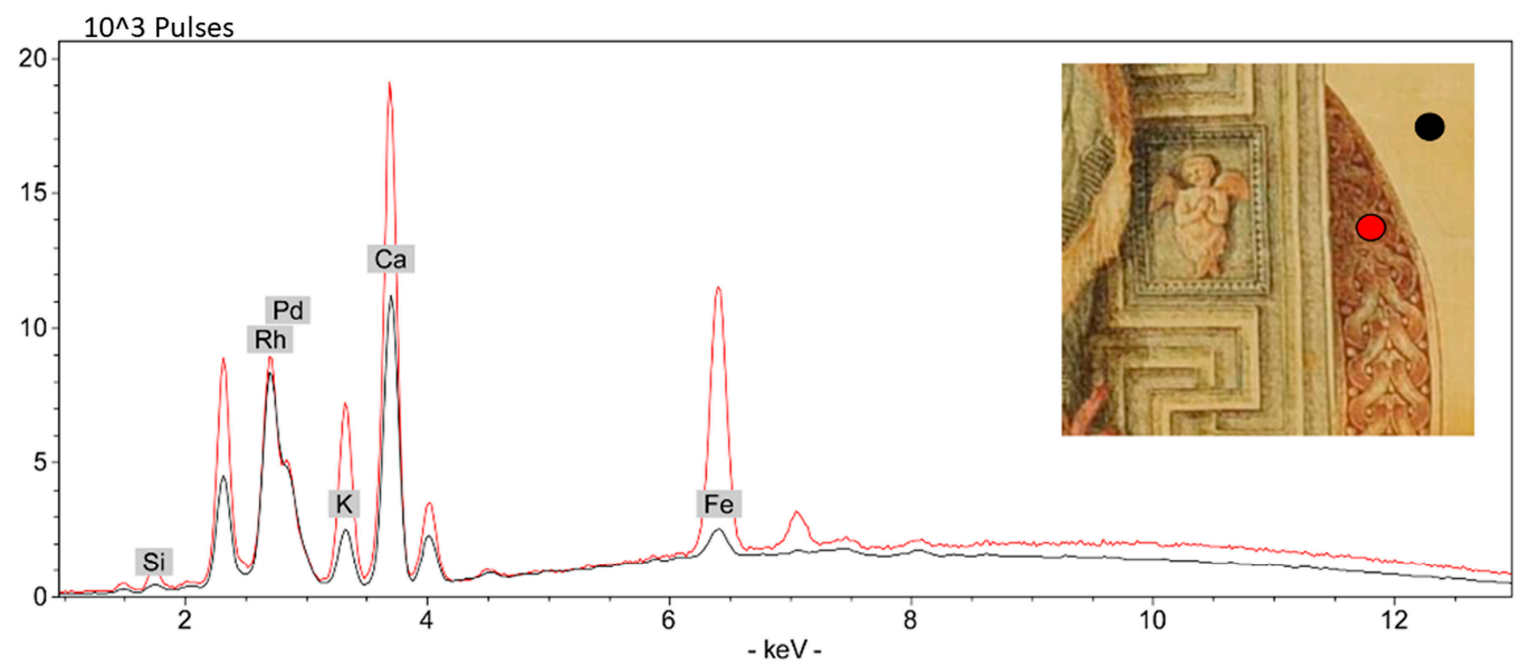

Figure 6. XRF of two areas on the chasuble. The spectrum on the silk is reported in black and the spectrum on the red decoration in red. Rh and Pd peaks pertain to the device's components.

Only the green leaf of the decoration on the stole differs from the other points, presenting high counts of copper (Figure 7).

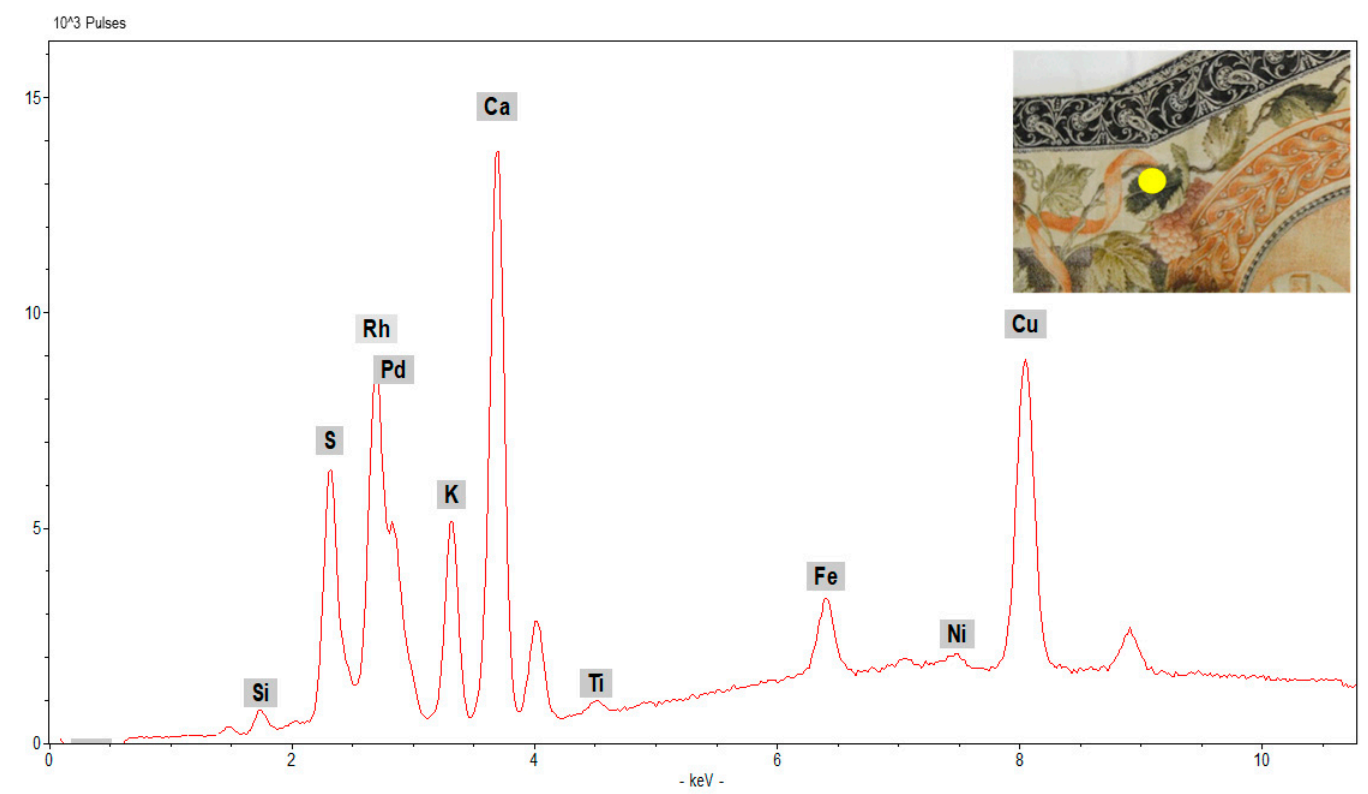

Figure 7. XRF of the green leaf on the stole where the lines of copper are visible.

\subsection{SEM-EDS, FT-IR, MicroRAMAN, GC/MS Survey: Micro-Analysis on Fragments}

As aforementioned, two detached fragments from the chasuble, provided by the restorer and shown in Figure 8, were analyzed by micro-invasive, non-destructive or micro-destructive techniques. 


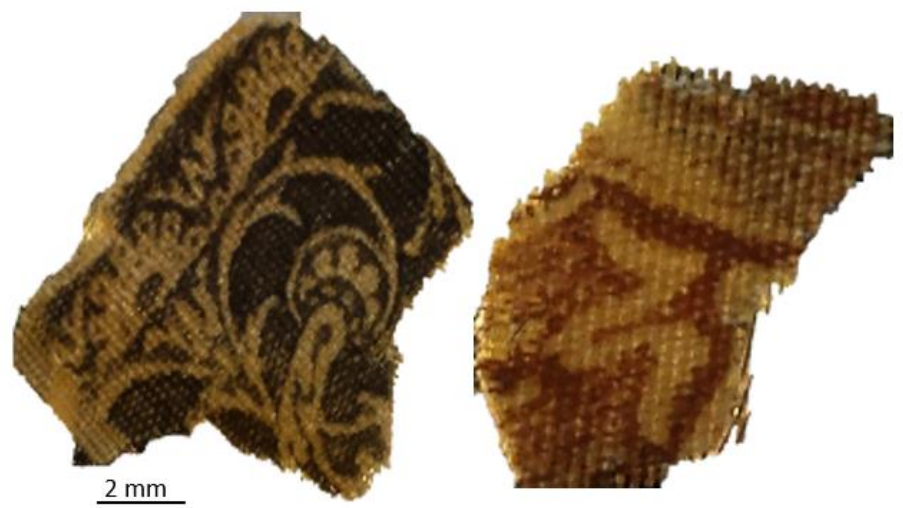

Figure 8. Detached fragments from the chasuble.

Observations under the UV light microscope showed the intrinsic blue luminescence emission of proteinaceous materials such as the silk [40-42], while no emission was visible in the painted (black or red) areas due to the absorption of ultraviolet radiation from these pigments.

Detail of the painted silk fibers under SEM is shown in Figure 9.
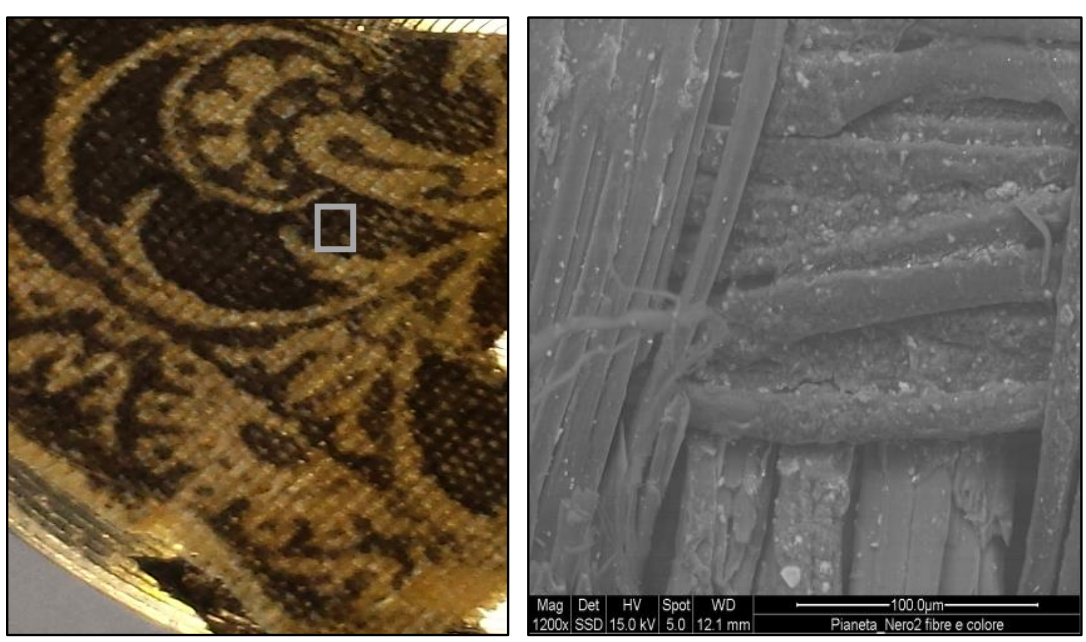

Figure 9. Detail of a black area of the fragment observed under the scanning electron microscope (1200× magnification).

The elemental analyses performed by SEM-EDS on the unpainted areas highlight the presence of elements linked to the silk protein (nitrogen and sulfur) and to superficial materials (aluminum, silicon, calcium and potassium).

Spectra acquired on the black-painted areas show an elemental composition similar to the silk support (Figure 10). As indicated by XRF measures, the absence of key elements on the black areas suggests the use of carbon-based black pigments. This evidence could be endorsed by the presence of a higher net count for $\mathrm{K}$ [44]. Al, $\mathrm{Si}, \mathrm{K}$ and $\mathrm{Ca}$ are elements related to superficial incoherent deposit 

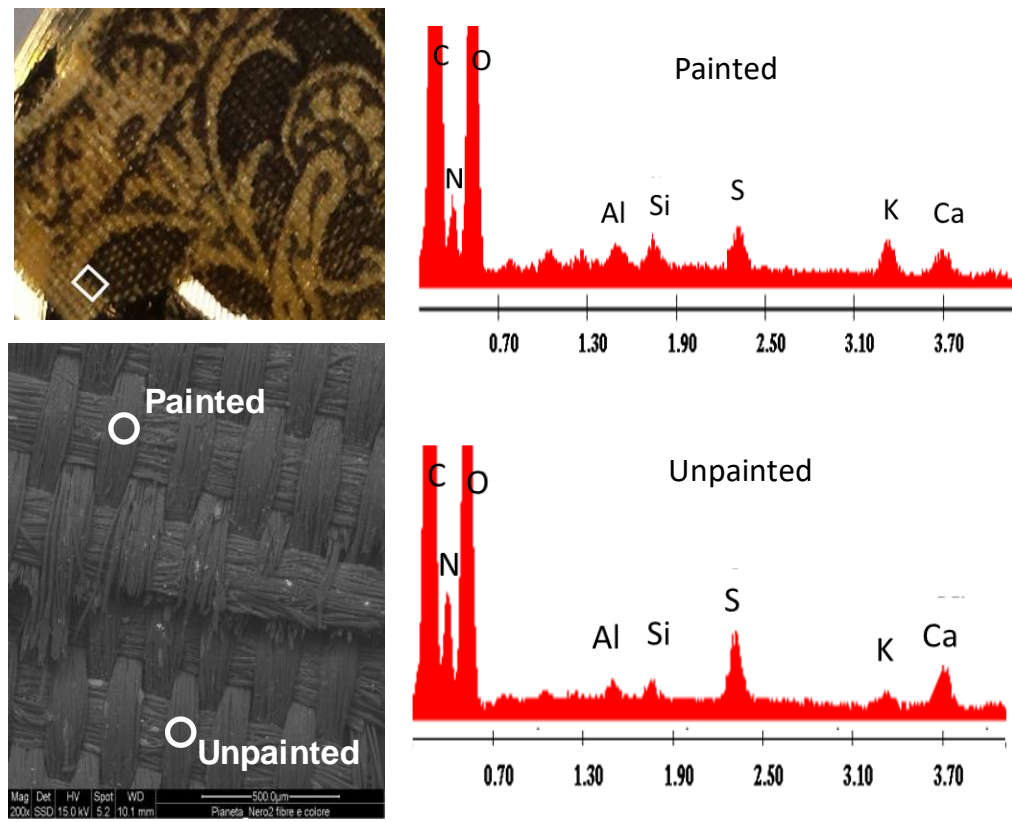

Figure 10. Detail of a black area of the fragment, observed by scanning electron microscope $(600 \times$ magnification).

SEM observations on the red fragment reveal compositional differences between the painted (lighter) and unpainted (darker) areas (Figure 11). These data suggest the presence of a pictorial layer containing a heavy element. This evidence is confirmed by the presence of iron (Fe) counts revealed in these areas (Figure 12), attributable to reddish iron earth pigments.

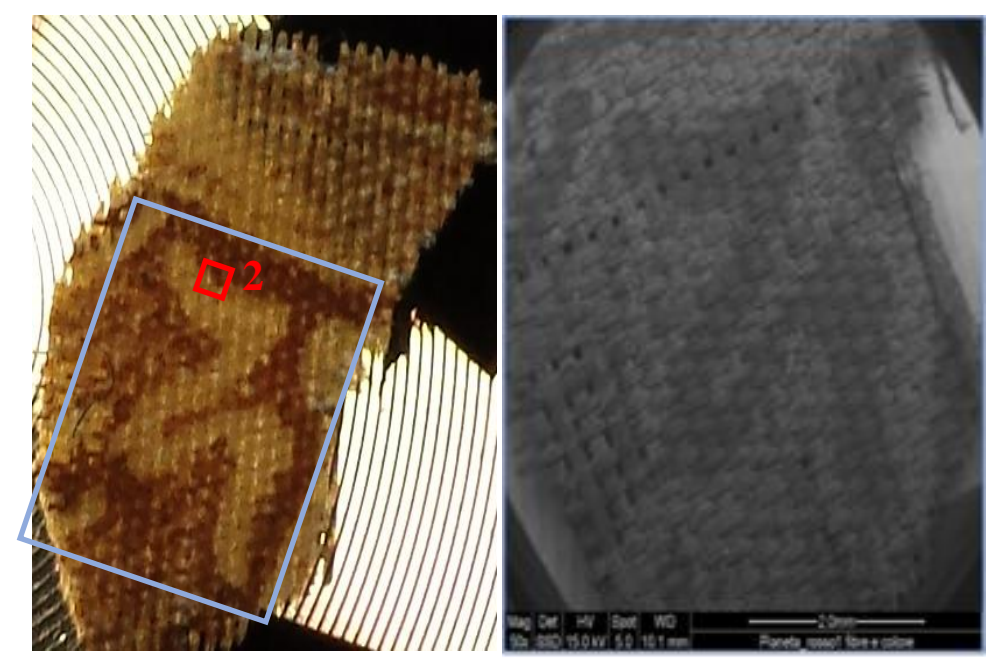

Figure 11. Optical microscope image (left) showing the areas analyzed by SEM (blue and red squares) and SEM image in backscattered electrons of area 1 (right). 

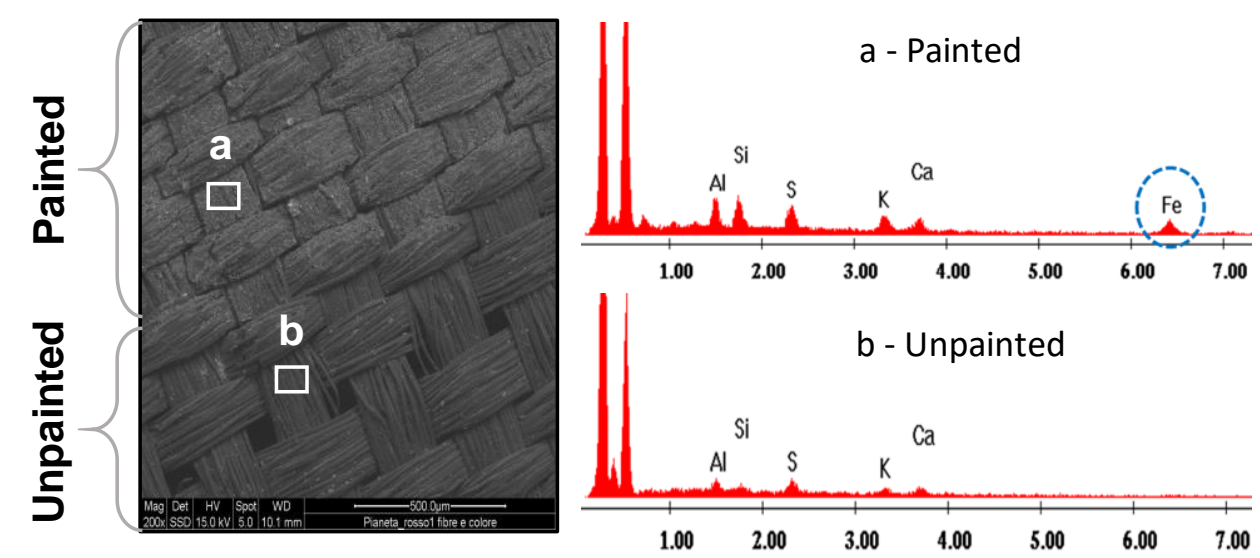

Figure 12. SEM image of area 2 (magnification $200 \times$ ) and spectra of a painted (spectrum 1) and an unpainted area (spectrum 2).

By comparing the spectra relative to the decorated areas of both fragments, the peak of the Fe is observed, but in the red fragment, the element shows higher counts, suggesting the use of an iron-based pigment. This outcome agrees with the results obtained with the XRF technique on the fragments (Figure 13). In addition, the presence of the weak peak of Fe in black areas may be related to the iron-gall ink hypothesized above for the hatching in the background.
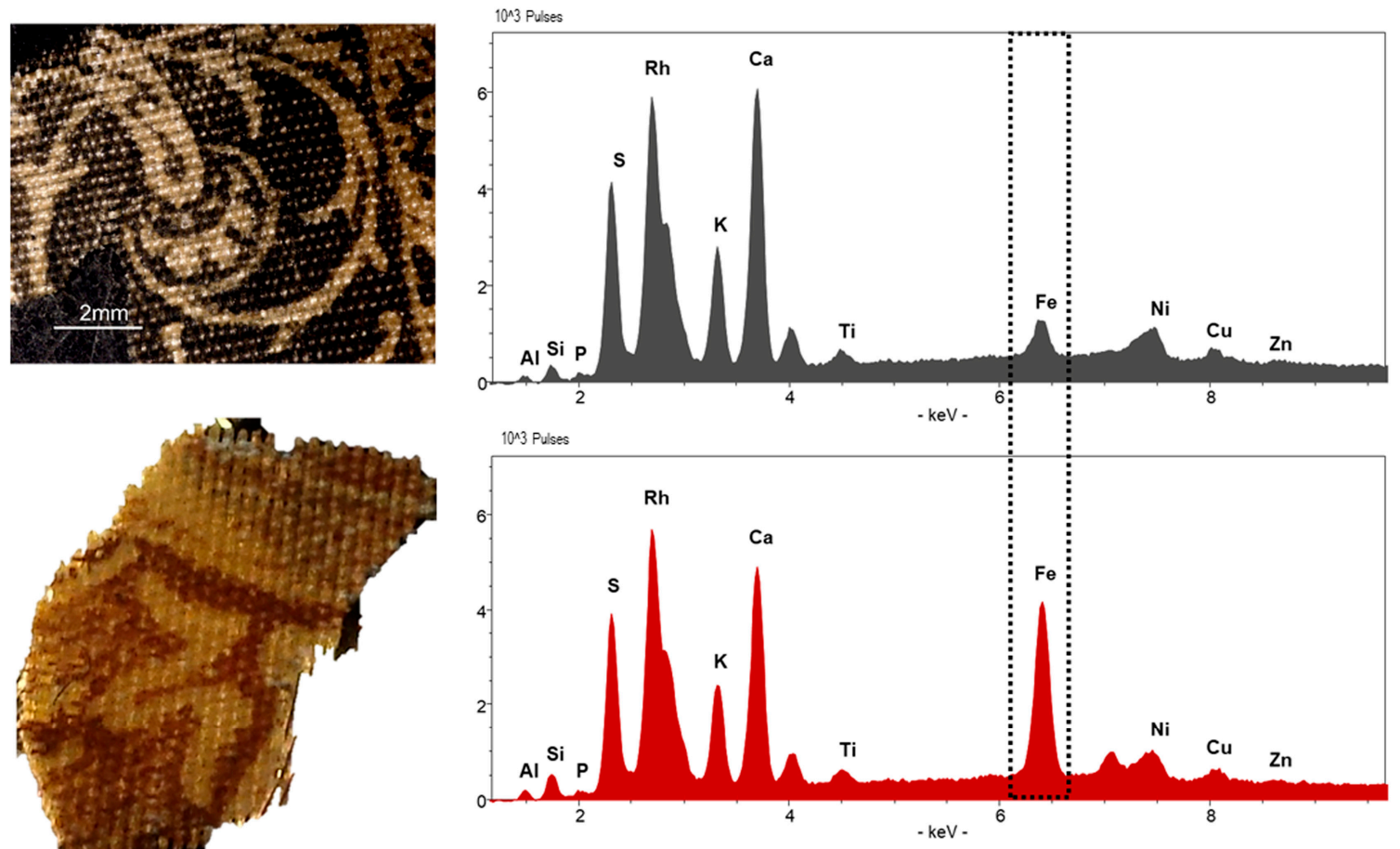

Figure 13. Comparison of the XRF spectra of the black and red fragment.

Raman analysis of the red-painted areas allowed for the pointing out of the presence of one band at $1583 \mathrm{~cm}^{-1}$, attributable to the symmetric E2g vibrations of the carbon rings in the plane of the graphite sheets [45] (Figure 14a) and the typical bands of iron pigment hematite $\left(\alpha \mathrm{Fe}_{2} \mathrm{O}_{3}\right)$ at $429 \mathrm{~cm}^{-1}$ (Figure 14b) [32,46]. The presence of graphite could be related to the underdrawing or to the shadow on the red hue. 

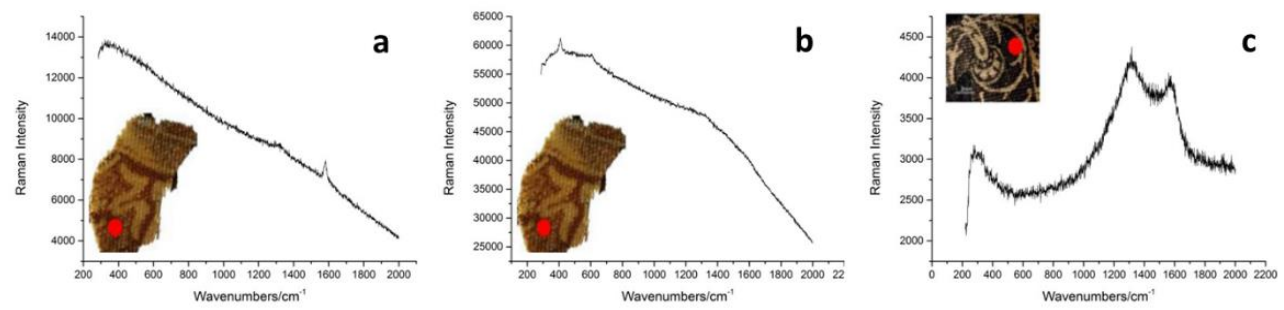

Figure 14. Raman spectra of the areas analyzed on the fragments. On the red fragment: (a) graphite; (b) hematite. On the black fragment: (c) amorphous coal.

On the black fragment, the Raman spectroscopy suggested the use of amorphous carbon as a pigment (Figure 14c). The spectra are characterized by two bands at approximately 1355 and $1600 \mathrm{~cm}^{-1}$, which are the D and G bands of carbon materials, respectively [33,47]. In amorphous carbon the two Raman bands are broad; furthermore, they can vary in relative intensity and width in relation to the degree of disorder or crystallinity, thus providing structural information on the compound and its preparation [48-50].

All microFT-IR spectra show the characteristic peaks of silk proteins; in particular, the amide band at $3273 \mathrm{~cm}^{-1}$ and amide I and II peaks at 1626 and $1510 \mathrm{~cm}^{-1}$, respectively [29-31]. Nevertheless, the spectra obtained on the painted parts (Figure 15) show the presence of a band at $1030 \mathrm{~cm}^{-1}$, attributable to the $\mathrm{C}-\mathrm{O}$ stretching band of a polysaccharide [28]. Comparing the spectra with standard references, the use of Arabic gum as a pictorial binder is presumed [5].

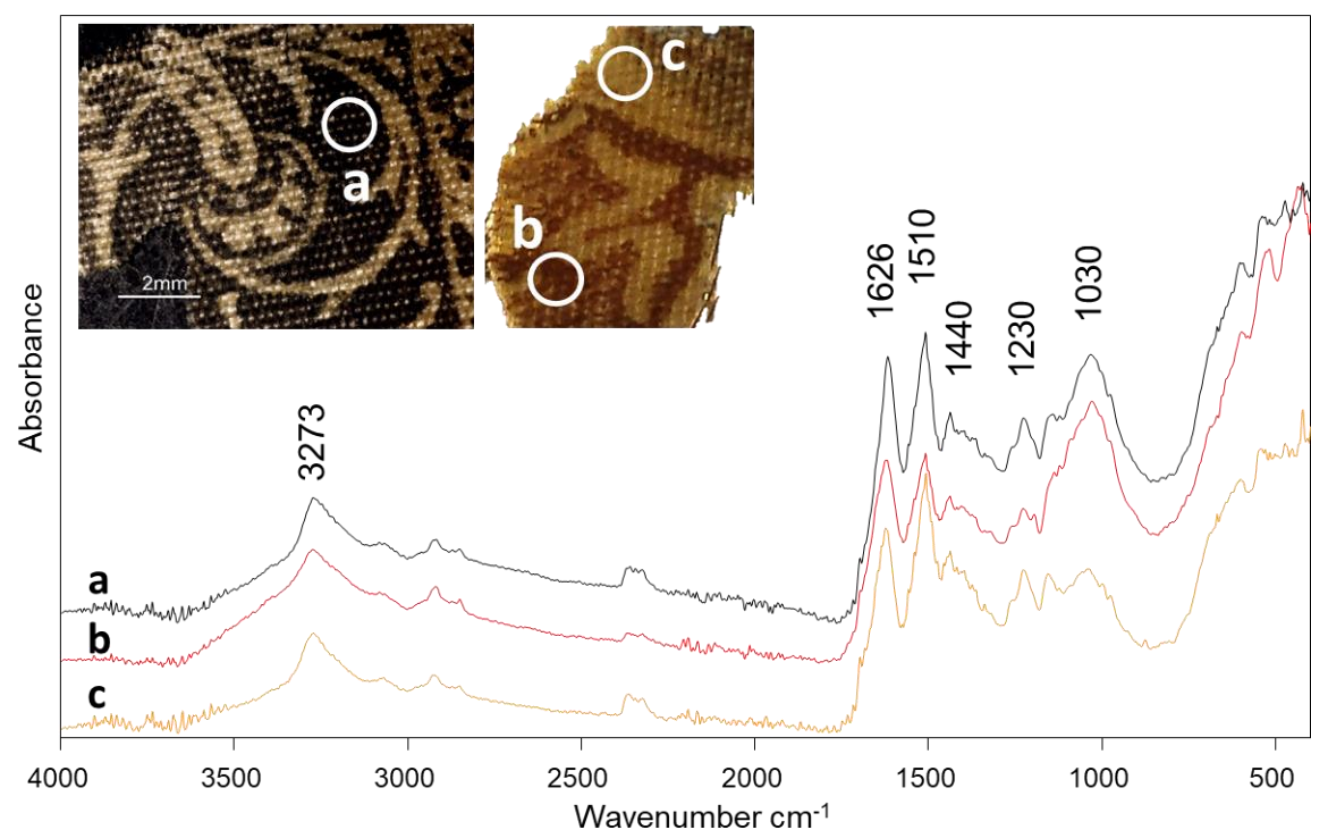

Figure 15. FTIR-ATR spectrum of (a) black-painted area, (b) red-painted area and (c) uncolored area.

GC-MS analysis underlined the presence of organic material in significant quantities in the samples. In particular, the analysis of the resin glycerolipid components [34] of the samples showed the absence of natural waxes, natural resins or siccative oils. On the contrary, saccharidic material is present in both samples. Table 2 shows, for each sample, the relative percentage of each saccharide or uronic acid, and in the last column, the total saccharide content in $\mu \mathrm{g}$. The sugars (or uronic acids) present were considered only for the amounts above the quantitation limit. 
Table 2. Saccharide content of the sample (RS: red sample, BS: black sample).

\begin{tabular}{|c|c|c|c|c|c|c|c|c|c|c|}
\hline 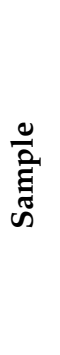 & $\frac{\ddot{D}}{\stackrel{0}{*}}$ & 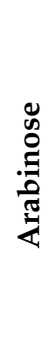 & 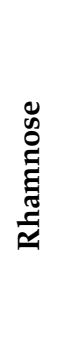 & 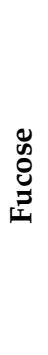 & 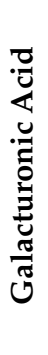 & 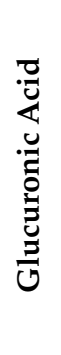 & $\begin{array}{l}0 \\
0 \\
0 \\
0 \\
0\end{array}$ & 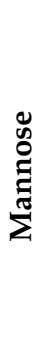 & 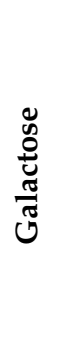 &  \\
\hline RS & - & 33 & 12 & - & - & 11 & - & - & 44 & 1.6 \\
\hline BS & - & 39 & 12 & - & - & 8 & - & - & 41 & 2.4 \\
\hline
\end{tabular}

The samples have a saccharidic profile characterized by both pentose and hexose sugars with the presence of glucuronic acid. The range of monosaccharides found is associated with the presence of a natural rubber [34,51,52]. In particular, the presence of arabinose, rhamnose, glucuronic acid and galactose, as reported in Table 2, indicates the use of an arabic gum in both samples, in agreement with the results obtained with microFT-IR-ATR.

\section{Conclusions}

The peculiarity of these liturgical vestments lies in the fact that they are painted, and not embroidered with colored threads such as the textiles traditionally made in this period. Application of the multi-analytical protocol presented here on this ancient liturgical set enabled the materials used to be characterized and helped to define the peculiar execution techniques used.

A preliminary observation performed by imaging techniques, especially near-infrared photography, allowed the presence to be highlighted of an underdrawing made with a carbon pencil and mainly outlined by a very thin line. Infrared reflected false color better highlighted the difference among pigments, especially the darker ones. Ultraviolet luminescence revealed the presence of organic materials. The technique was useful to identify red lacquer used to create a pink pattern and decoration, but also to delimitate stains and organic residues on the silk. Most of the painting materials analyzed are organic pigments and are therefore not detectable by XRF. However, the technique revealed the use of iron-based pigments for red and brown tones and a copper-based pigment for green areas.

It was also possible to study two fragments detached from the chasuble. Microinvasive, non-destructive or micro-destructive techniques were used to integrate the information obtained in situ. The analytical data confirmed the use of iron-based pigments to decorate the drawing and brown backgrounds and a carbon-based pigment for the black areas. Analysis through GC-MS on the binder identified it as Arabic gum.

Author Contributions: Conceptualization, D.M., S.B., R.I. and B.S.; Data curation, D.M., S.B., R.I. and B.S.; Formal analysis, D.M., S.B., R.I. and B.S.; Investigation, D.M., S.B., R.I. and B.S.; Methodology, D.M., S.B., R.I. and B.S.; Project administration, Lucia Nucci; Visualization, D.M., S.B., R.I. and B.S.; Writing—original draft, D.M., S.B., R.I., B.S. and L.N.; Writing—review \& editing, D.M., R.I. and B.S. All authors have read and agreed to the published version of the manuscript.

Funding: This research received no external funding.

Institutional Review Board Statement: Not applicable.

Informed Consent Statement: Not applicable.

Acknowledgments: The authors wish to thank Ilaria Degano (Dept. of Chemistry, University of Pisa, Italy) for GC-MS characterization of the binder and Cristiana Lo Frumento (Dept. of Chemistry, University of Florence) for Raman analyses of the red and black pigments. 
Conflicts of Interest: The authors declare no conflict of interest.

\section{Appendix A}

Appendix A includes a detailed description of the iconography, state of conservation and conservative intervention performed on the liturgical set.

\section{Appendix A.1. Historical Notes about the Papal Clothing and Don Saverio Caselli}

The ecclesiastical vestment, with insignia, of Pope Pius VII, which belongs to a descendent of the Pope, Count Gregorio d'Ottaviano Chiaramonti, is made of five clothing elements: chasuble, stole, maniple, chalice veil and purse [53,54]. It is a rare example of a chasuble and its accessories painted from the end of the 18th up to the beginning of 19th century, in the 12 years between 1795 and 1806, which were included in the assets of the Counts Chiaramonti after the death of Pius VII, when his personal belongings were divided up between his heirs on 25 September 1826 .

The neoclassic-style decoration, painted on pure silk ermesino, was created by the priest-architect Saverio Caselli, as documented by the signature on each textile element. He was a clergyman and architect of great skills, from a minor noble family, although little known in the artistic world. He was an architect in the papal town of Benevento and as superintendent of the bishop's building projects, was put in charge of the construction of a bridge on the Cadore river in Benevento. In 1888, a textile workshop was created in the Santissima Annunziata Conservatory of Benevento with Saverio Caselli as director. Since he was already known in town as an architect, he was given the responsibility of supervising the construction and organization of the conservatory and later of its accounting, at least at the beginning of its activity. The level of such works was rather high, since great care was taken in the improvement of technology and machinery, using premium quality materials. For this reason, such high-quality textile works, durable in time, were popular in that petit bourgeois setting [55].

Caselli was intimately connected to the Papal Court: his father had been the personal physician of Cardinal Vincenzo Maria Orsini of Gravina, who later became Pope Benedetto XIII, which brought his father the nomination of valet of honor to Pope Pius VII in 1818, and subsequently the supernumerary valet to Pope Leone XIII in 1822.

\section{Appendix A.2. Description of the Artifacts}

The five handicrafts have similar decorations, which are not, however, identical in all the pieces. It consists of very refined geometric patterns, organized around a Greek-style freeze with sepia, grey and green tones, and inserted squares in which flowered garlands and a ribbon of okra gallons are interwoven, reducing the rigidity of the freeze. These three components relate to grey elements mimicking sculpted figures. The composition of vegetal garlands varies in the different artifacts, sometimes as a simple laurel motif, or with the addition of flowers, vine leaves, wheat sheaves, ivy shoots, pomegranate branches or roses, but each element has a different symbolic meaning.

The chasuble has a Roman shape and is cut in "ermesino" natural silk, shining and of high quality, like the other parts of the clothing. It is made of two parts sown together and painted before mounting. The column and the tau in the front are outlined and made evident by a geometrical decoration, a rectangular ribbon with an edge of trimmings and a garland of leaves and wheat sheaves in a ribbon. The freeze is rhythmically interrupted by squares representing cameos with winged cherubs. Such images are rectangular-shaped on the vertical side of the tau and egg-shaped on its horizontal side. The spaces between the garlands are adorned with different subjects: on the front side at the base of the tau, within a medallion, is a Pelican-Christ feeding his children-flock, between two cornucopia, which are symbols of abundance. Above this image the arma Christi are represented as a large trophy, and above this, in another medallion, the lamb of Christ is sacrificed on an altar beneath a dove, which represents the Holy Spirit. Over the Holy Spirit, bunches of grapes and sheaves of wheat are depicted, symbols of Eucharisty, and finally a large bunch 
of light blue flowers, probably forget-me-nots, as the symbol of fidelity and everlasting love. On the right side of the casula, a fly is painted next to the garland.

On the back side, between two almonds, there are two images: on one side is a bronze snake curled around the tau and on the other a victorious cross rising over the world, dominating the tree of the knowledge of good and evil, placed in the center between Adam and Eve. Below is the coat of arms of Pope Chiaramonti, depicted on a cornucopia, a symbol of abundance, with two little angels that have butterfly wings. One of them has a little incense box in its hand, the other a laurel branch. Below that, there is a square, mimicking an inscription carved in stone, with the signature: Sav. Cassel/li Archo Benevo delin. e fec. 1804/D.D.D.

The stole has a cross in the center, embroidered on tulle, with palm leaves at the top, and is adorned with a central ribbon with a geometric decoration, smooth and rectangular along all its length. On this ribbon, a gallon of trimmings is interwoven, forming a design of the number eight, alternated with a garland of thick leaves on a red ribbon, sometimes affixed with bows. At the intersection of the branches of this eight, several images are represented, mirror-like on each side of the stole: the chalice, two crossed keys and finally a big book, which we presume to be sacred. Wheat sheaves and grapevine leaves are spread across two big oval medallions adorning its extremities. One medallion shows the glorification of the cross sustained by the three theological virtues: Faith, Hope and Charity, which crush a demon represented by a female figure; on the medallion at the other extremity, the angels of the final judgement are represented, one of whom is blowing a small trumpet. The others brandish a cross overhanging the composition, while the faithful are resurrecting from the kingdom of the dead. On the arms of the cross, a cartouche with the words "Hoc signum erit in coelo" is wrapped. On one side of the lower edge is the writing: S. Sav. Caselli. A: D.D.D. A. 1805, and on the other: Caselli Arch. s. Benevent. s. Fecit.

The maniple shows the same ornamental pattern as the stole. Next to the central rose window embroidered on tulle, representing a cross with geometric decorations, we find two rectangles, one with a quiver and the other with butterflies. The border is surrounded by trimmings, crossed with a flower garland and two bundles of wheat sheaves with grapevines and leaves. On the sides, two small squares in the freeze again show a quiver and butterflies. Each extremity contains a hexagon surrounded by small trimmings, with two small angels and cherubs sustaining the cross. On the lower edge, a script in ink says: Xavier. Caselli. F.

The veil of the chalice, square in shape, has a light and elegant structure, divided into four triangles by a Saint Andrew cross, the border of which is outlined by a meandering geometric decoration and by small slabs with golden stubs; the empty spaces are ornate with vine leaves, wheat sheaves, roses and passion flowers. At the center of the base of each triangle, there is a medallion with a bell shape, surrounded by the ribbon of a gallon. These medallions, almost bas-reliefs, are characterized by winged creatures dressed in old robes, each one different, in the shape of angels or spirits of the forest. Two of the creatures hold a censer over the altar, another one squeezes a bunch of grapes over a chalice and the last one tries to throw a crown of leaves into the fire. At the four corners of the veil, precisely inserted at the four ends of the Saint Andrew cross, the tetramorphic representation of the Evangelists is inserted, in a circle, under braziers shaped like pots with handles. 
At the center, in a quadrilobe, it is possible to read the three letters HIS ${ }^{1}$ (Iesus Hominum Salvator), of a small dimension, surrounded by flames. On one of the sides, at the center of the lateral border and under the bell-shaped medallion containing the profile of a winged creature throwing a flower garland, a small handwritten inscription is visible: Sac. D. Xavier. Caselli. Arch. Beneven. delin. ora 1212 A. 1798.

The decoration of the purse is characterized by an abundance of grapevine leaves with fruits and flowers, among which the passionflower is predominant. The structure of the composition is as follows: the cloth ribbon describes a four-sided image or Greek cross, in the center of which a lozenge shape with rounded borders stands out, which contains a fake embroidery on linen canvas representing a Greek cross. The Greek cross cloth decoration is interwoven with a rectangular ribbon at its perimeter and is characterized by geometrical shapes. This border is rhythmically centered on each of the four sides by rectangular shapes containing the instruments of Christ's passion: the column, the whip and the ropes; the spear and the sponge; the ladder, the pincers and the hammer; the crown of thorns and the rods. In the four corners of the rectangular border, four round splayed and perspective windows are visible, from which plenty of vine leaves full of grapes emerge. On the border of one of the sides of the quadrangle, the signature in black ink is visible: S. Xav. Caselli Archs. Benus. S.C.B.R. inc. ac. F. men. Jan.1795.

\section{Appendix A.3. Decoration and Iconography}

The technique used is drawing, underlined with water colors with pastel tones. Grey, pink, golden yellow and faded green are the predominating colors. This type of decoration is not typical of the period for liturgical clothing, and it appears related to the ornamental style of mural decorations, as you might expect from an architect. The attention to detail of the artist is also noticeable in the architectural shades from one element to the other. The same holds true for the inscription in the square under the casula, reminiscent of monumental sculpture. This decoration is characteristic of the last years of the 18th century. The Greek-style freezes, underlined at the corners by cameos, are found in several designs of the goldsmith craft of Luigi Valadier; for example, the triumph of Bacchus.

The iconography is inspired by the Passion of Christ and the salvation associated with the Eucharist, which was very popular in the 18th century. The lamb sacrificed on the alter, the pelican symbol of charity and the Eucharist, the arma Christi, are found in numerous works; on the casula, the salvation cross under which the dead are resurrecting on judgement day is opposite to the bronze snake. The iconography of the veil is even more directed towards the sacrifice of praise, with angels surrounding the altar and tetramorphic images introducing the Gospel as Logos, the Word of Salvation. The symbolic meaning is important: the representation of the Passion is expressed ecumenically as torn between pathos and salvation, where everything leads to salvation through the Eucharist, represented also by the chalice of wine. The wheat sheaves, garlands of vine leaves and flowers also evoke the Eucharist as a liberation and send a subliminal message in the context of the tragic end of Pius VI and the difficulties of the Pontifical reign of Pius VII. The lamb sacrificed on the altar, the pelican feeding his offspring with his own flesh (the faithful) and the arma Christi remind of the sacrifice of Christ. They exalt, at the same time,

\footnotetext{
1 "IHS (or JHS) is a Latin transcription of the Greek abbreviation of the name of Jesus 'Inбoṽ s, capital IH $\Sigma O \gamma \Sigma$ ) as written in Greek manuscripts or inscriptions. Reading the $\mathrm{H}(\eta)$ like an $\mathrm{h}$ originated the erroneous interpretation of the script, like Jesus Hominum Salvator. Such a script was spread in Italy and Spain from the 14th to the second half of the 15th century, in particular by the work of Bernardino da Siena and followers, who, as a symbol of a particular devotion to Jesus' name, took it as an emblem, surrounded by rays and with a vertical addition to the middle bar of the H to form a cross. Ignatius de Loyola adopted it, surmounted by a cross, as an emblem of the Jesus Congregation (Enciclopedia Treccani).

"Contrary to popular opinion, the monogram does not indicate "Jesus Hominum Salvator" or "In Hoc Signo". IHS is more appropriately defined as "crystogram", or an antique way of writing "Jesus Christ" originating in the 3rd century. The Christians abbreviated Jesus' name, writing only the first three Greek letters IH $\Sigma$ (from the complete name IH $\Sigma$ Or $\Sigma$ ). The Greek letter $\Sigma$ (sigma) in the Latin alphabet became a "S", and this originated the script IHS. In the first centuries in the church, this was a secret symbol, often carved in the tombs of the Christians. After, in the 15th century, Saint Bernardine of Siena organized a preaching campaign to promote the reverence to the holy name of Jesus and encouraged the Christians to put a HIS over the door of their houses. A century after, in 1541, Saint Ignatius adopted the monogram to represent his newly founded order, the Jesus Society (Jesuits). The symbol is now widespread in all the Christian areas of the world", Philip Kosloski, in Aleteia, 16 May 2017.
} 
the Roman Pope, elected in difficult times in March 1800, prevailing with his diplomatic efforts and pugnacious will on the impiety of the French revolution, striking down the bronze snake and making the glorious cross triumphant again.

The incense that is generously represented and the abundant cornucopias surrounding the pelican on which his weapons are posed represent the hope that he restored amongst the Catholics. Lastly, the representation of the two crossed keys refer to the ministry of the Pope, like the keys of heaven entrusted to Saint Peter. The keys are one of gold and one of silver, symbolizing the power of the Pope to unbind and bind.

\section{Appendix A.4. The Conservation Treatment}

The conservation process is a great opportunity for the understanding of an artifact. Together with the analytical research from which it originates and to which it is intrinsically interconnected, it represents perhaps the most capillary and profound analytical phase, since it investigates the most hidden components of the materials, superimposed or stratified over the course of history.

The work is based upon three fundamental aspects that make up the overall fully fledged knowledge of a cultural artifact. The first aspect is the "historic content", to quote Brandi, starting from the most famous academic studies, accompanied by notions taken from sources not so obvious in traditional studies, yet it can be considered a real final asset in completing an "identity card" of the cultural artifact. The second aspect is the technical map, fundamental in this type of work, which requires the specific knowledge and cooperation of various disciplines (art history, chemistry and physics), associated with specific conservation experts. The third aspect is that the more we penetrate the mystery of "conservation", the more we appreciate the importance of the "third act", as Umberto Baldini would say. Which means that through restoration one gains a more complete picture, in greater detail and accuracy, of the artifact and its history. Without the prestigious exhibit in Paris, this rare and extraordinary work of art would no doubt have remained hidden for a long period of time, stored in the wardrobes of the palace belonging to Count Gregorio d'Ottaviano Chiaramonti, without the opportunity of being known and admired in a public exhibition and published in a catalogue.

\section{Appendix A.5. The State of Conservation}

The ecclesiastical clothing in question was stored in a wardrobe of the palace in Cesena belonging to Gregorio D'Ottaviano Chiaramonti. When it arrived, the chasuble was not in good condition. It was covered by a thick layer of dust or incoherent particles all over its surface. The undecorated silk had lighter lines and stripes, as if the tissue had been scratched.

In the recto, to the right of the undecorated silk, a big stain of $35 \times 10 \mathrm{~cm}$ was evident. Many smaller stains were present on the whole surface. The textile was very worn, but with no cuts or missing parts. In the area of the shoulders, the color of the silk was darker, tending to a yellow color and with evident shredding.

In particular, a loss of tissue of $5 \times 5 \mathrm{~cm}$ was evident in the right shoulder, close to the edge, where the design was totally missing. Moreover, on this side, the main cloth was detached from the lining for $23 \mathrm{~cm}$.

From this loss, three cuts originated: one of $5 \mathrm{~cm}(\times 1)$ in the direction of the anterior part, one lateral of $4 \mathrm{~cm}(\times 1)$ and one of $10 \mathrm{~cm}$ towards the back $(\times 1.5)$. Under these cuts, in the direction of the front side, there was another $3 \times 0.3 \mathrm{~cm}$ missing space. The left shoulder showed a small missing space of $0.4 \times 0.2 \mathrm{~cm}$ and a cut of $3 \times 0.2 \mathrm{~cm}$.

On the back, confluent big stains of a yellow ochre color could be seen. They are evident especially in the parts without design. Three more evident stains were located on the lower right side; going from top to bottom: one oval stain of $14 \times 10 \mathrm{~cm}$; one S-shaped stain of $14 \times 10 \mathrm{~cm}$; one oval stain of $4 \times 5 \mathrm{~cm}$. Some lighter zones were also located next to the central design, one oval of $3 \times 2 \mathrm{~cm}$ in particular. 
Eight cuts were present along the decorated right border, two of which were horizontal and very evident, caused by dried folding. On the left, in the undecorated part, a very deteriorated zone of $15 \times 19 \mathrm{~cm}$ was visible, caused by rubbing.

The chasuble had 25 cuts, stains, discoloration and dry folding. There were 25 cuts in the part close to the border, ranging from 0.5 to $6 \mathrm{~cm}$, three horizontal and the other 22 vertical.

The conditions of the stole cannot be defined as optimal. A diffuse and light layer of dust covered the very fragile cloth, with cuts at the two extremities of a size variable from 1.5 to $1 \mathrm{~cm}$. No big stains were evident, but only smaller ones with a diameter of approximately $0.5 \mathrm{~cm}$. On the lining of the stole, apart from the dust, two stains were visible at the extremities (Figure A1), one on the left of approximately $42 \times 5 \mathrm{~cm}$ and one on the right of $45 \times 10 \mathrm{~cm}$.

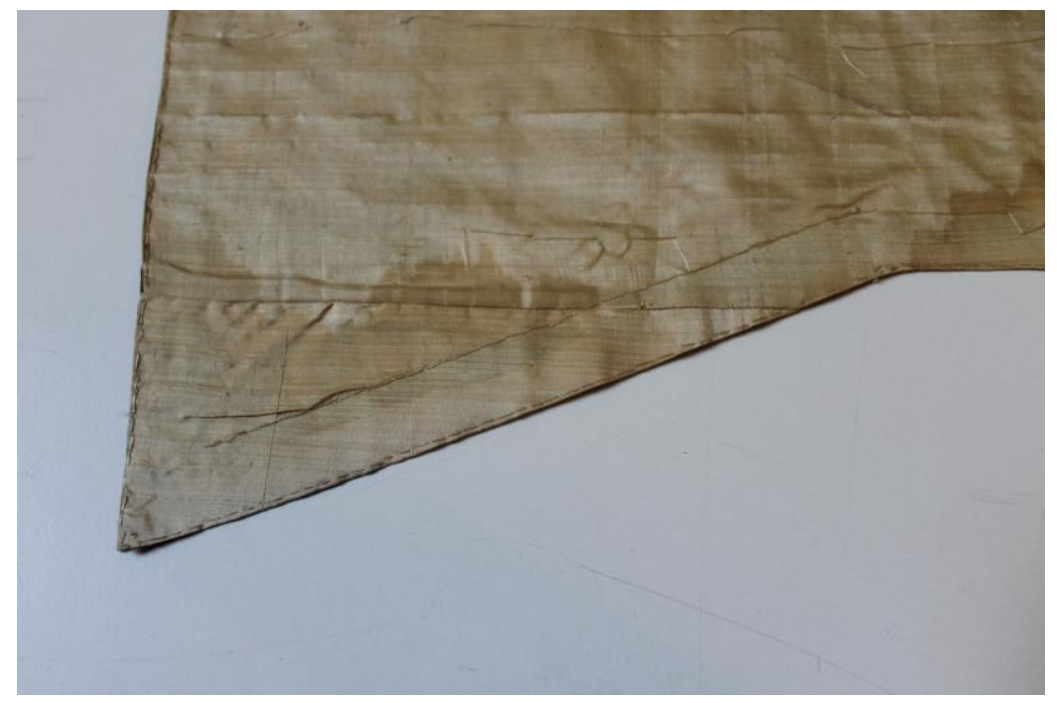

Figure A1. Detail of an area on the verso of the stole.

There was also an additional one of $2 \times \mathrm{cm}$. The lining was intact, with no cuts or gaps.

The conservation of the maniple was acceptable: besides the widespread dust on the whole surface, the most evident characteristic was the presence of very lively colors on the right side, indicating that it was likely sketched and assembled sometime later than the left side. There were no evident stains, just little ones in proximity of the geometric design. The lining, smaller than the principal clothing, caused the formation of cuts. Described in more detail, beginning from the lighter zone on the left, next to the border, a small $12 \mathrm{~cm}$ long vertical fold was created, which caused a cut $9.5 \mathrm{~cm}$ long. A horizontal cut of $3 \mathrm{~cm}$ was also visible.

On the border, two gaps of approximately $1.5 \times 0.2 \mathrm{~cm}$ were present. The border was very worn, almost to the point of being open. Continuing the analysis of the cloth, it showed an evident vertical fold in the central area going from the left to the right border, which caused the cloth to be worn to the point of being torn. There were four cuts caused by the dry folding, three of $2 \mathrm{~cm}$ and one of $4 \mathrm{~cm}$. The border, where the cloth has the brightest colors, had a long vertical fold of $13 \mathrm{~cm}$, which caused a cut of $10 \mathrm{~cm}$. Moreover, at $3 \mathrm{~cm}$ from the border, a vertical cut of $4.4 \mathrm{~cm}$ was visible. In addition, in this area, the border was very worn.

The two lateral folds, next to the borders, correspond to the inverse sewing, which holds the lining and the principal cloth together. Two small gaps of $0.2 \times 0.2 \mathrm{~cm}$ were present on the borders.

The maniple lining was in excellent condition, except for some dust evident on the surface. The cloth was intact, with no stains, discoloring or holes. 
The little ribbon was also in acceptable condition, showing a widespread dust layer which dampened the original brightness. There were evident diffuse yellow stains, especially at the extremities. The ribbon had rolled borders for $28 \mathrm{~cm}$ on both sides.

The chalice veil was in moderately good condition of conservation. Besides a widespread light layer of dust on both sides, it had numerous small oxidation stains, which were very evident in the sections without the design. Analyzing the front side, the presence of single oxidized threads is evident because of the almost brown color. A big $12.5 \times 12.5 \mathrm{~cm}$ stain was also visible in the central part of the principal design in the lower part. It had the same shape as the frame containing the design. Furthermore, some holes were present: six very little oval-shaped holes with a diameter of $0.5 \times 0.3 \mathrm{~cm}$ and three vertical segments, measuring $3.5 \times 0.2,2.3 \times 0.2$ and $1.5 \times 0.2 \mathrm{~cm}$, respectively. The last two in particular were vertically placed over three other horizontal rips, caused by a fold on the left of the veil, located in the center between the borders. The back was complete without any cuts or breakages, but with evident small stains over the whole surface. The biggest stain of $14 \times 6 \mathrm{~cm}$ was on the upper left side. There were also two others of $8 \times 9$ and $3 \times 2.5 \mathrm{~cm}$, respectively. Another $1 \times 0.7 \mathrm{~cm}$ stain of a dark blue color was located on the upper edge. In general, both the oxidation marks and stains were barely visible because of their light color. On the right-hand border, a small group of Bordeaux red stains were, however, evident.

The purse was in a relatively good state of conservation. It showed a widespread layer of dust on both sides and three small round stains, two of which were due to oxidation; more precisely, one of $3 \mathrm{~cm}$ of dark ochre color, in the corner of the lower left-hand side, and a second one of $0.7 \mathrm{~cm}$ in the upper left corner near the design. The third stain was wax, placed horizontally on the right side, starting from the border for a length of $2 \times 0.2 \mathrm{~cm}$. Other very small oxidation stains were present over the entire surface of the purse. In addition, six oval stains with a maximum width of $0.4 \mathrm{~cm}$ caused a complete loss of the color and consequently of the design.

The textile was undamaged with the exception of the four corners, in which four holes were present, revealing the filling. The whole purse was slightly deformed due to the humidity absorbed by the filling material, which we presume was made of cardboard or parchment, both quite hygroscopic, and therefore easily deformed. The purse lining was also in a relatively good state of conservation, except for the presence of widespread dust and two oxidation marks, one darker of $1 \times 2 \mathrm{~cm}$ on the upper left side and one lighter of $1 \times 0.3 \mathrm{~cm}$. A small piece was missing on the vertical lower left end border, measuring $0.7 \times 0.5 \mathrm{~cm}$. On the opposite vertical side, next to the border, a small hole was present. The four corners of the lining showed a lack of cloth with holes of approximately $0.7 \times 0.5 \mathrm{~cm}$.

\section{Appendix A.6. Conservation Operations}

We performed a series of sequential interventions on every piece. More precisely, we started from sketches with the state of conservation, using permanent markers on Melinex ${ }^{\circledR}$ in order to establish legends with different shapes and colors and to underline the perimeter of the pieces, folds, cuts, missing pieces, discoloring, discoloring with folds, dark lines, Bordeaux stains, dark stains and foxing. On each piece and its respective lining, photographic images were acquired before, during and after the conservation process. We then proceeded to remove the dust with a low power micro-aspirator, which could be adjusted to the front and back side of each piece, on all surfaces and on the linings, after testing the micro-aspiration in order to establish the necessary power and duration of the machine's use.

The micro-aspirator was fitted with special blown glass cannulas of various shapes and dimensions, adaptable to all conservation conditions, for an accurate intervention for each aspiration required.

The lining was connected on the perimeter with the main cloth of the chasuble with stitches "a filza", with a distance from the border of $0.1 \mathrm{~cm}$. In addition, there were four sewing lines, the first at $4.5 \mathrm{~cm}$ from the border, the second at $7.5 \mathrm{~cm}$ and the third at $10 \mathrm{~cm}$. All these sewing lines were parallel to the perimeter of the vestment, both vertically and 
horizontally, with inverse sewing stiches at a distance that varied from approximately 0.5 to $1 \mathrm{~cm}$. At the neck, the chasuble was sown to the lining with an "under stitch", which was very abundant relative to the principal cloth, and therefore protruded $0.2 \mathrm{~cm}$ from the chasuble.

Only on the horizontal side did the lining not protrude, and was instead attached to the painted textile with "a filza" stitches. Although we tried to keep the original sewing intact in all of the pieces, since it was performed with particular materials that are no longer in use, and to respect the original manufacturing techniques, we nonetheless decided to undo some parts in order to be able to proceed to further phases of cleaning and consolidation.

We also dismantled the linings of the chasuble using surgical scalpels and scissors (Figure A2), and therefore tried to obtain some threads from the original silk stitching to use a thread of the same type and thinness to reassemble the individual pieces.

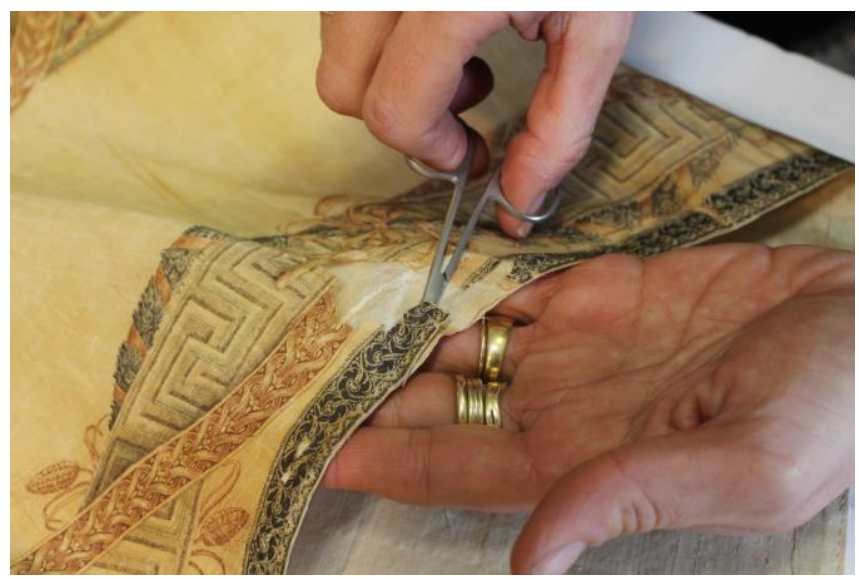

Figure A2. Detail of the dismantling of the linings of the chasuble.

Another fundamental phase for the preservation of the integrity of the extremely damaged cloth was to place some partial temporary supports in tulle or silk organza with long stiches of silk thread.

The cleaning of the chasuble was performed on the stained and discolored zones only, in particular on the parts without decoration. We prepared some cotton swabs covered with small pieces of cloth. Each cloth to clean was positioned on a portable table with low pressure, secured with small weights under which Melinex ${ }^{\circledR}$ was placed as protection. With these little cotton swabs, we cleaned the surface with deionized water. To speed up the drying and avoid further discoloring, whilst using the wet swabs, we simultaneously blew cold air.

The cleaning with swabs on the stains was not repeated more than twice because of the extreme fragility of the cloth, which might be broken or torn by rubbing.

The same cleaning method, with swabs on a low-pressure table, was performed on the lining of the chasuble.

For this phase we divided the chasuble in zones and sectors, with letters of the alphabet used to underline and document cuts and missing pieces. We began from the front in an area indicated with the letter " $\mathrm{A}$ " that was more degraded and susceptible to further cuts and losses of decorated zones and we arrived at the letter " $\mathrm{P}$ ". We decided to consolidate the original cloth with partial supporting material in organza-colored "givrè" silk. This cloth was wetted and dried on a glass table, the supporting material in direct stitch was then eliminated, and entomological needles were placed beneath the zones under restoration, trying to put together the borders of the cuts as much as possible. After that, we fixed the borders of the cuts or missing pieces with "filze" made of "givrè" organza threads. Additionally, the supporting cloth of the border was fixed with small "filze" of the same type of thread. In the area with losses of cloth, we placed organza sustainers and inserts of pure silk ermesino of the same nuance color as the chasuble, always attached 
with "filza" stitching, with thread obtained from "givré" organza. After restoration of the back, we proceeded with the front. The same procedure was followed with the lining, using "Lyon veil" instead of pure silk organza.

Coming back to the chasuble, after consolidation by sewing, we intervened on the inserts fixed in the areas with loss of cloth in order to add the missing design with water colors and silk of various nuances.

In order to reconstitute the decoration on the big missing zone on the shoulder, we reproduced the design of the intact part on Melinex ${ }^{\circledR}$ and transposed it onto the silk insert of the missing zone (Figure A3).

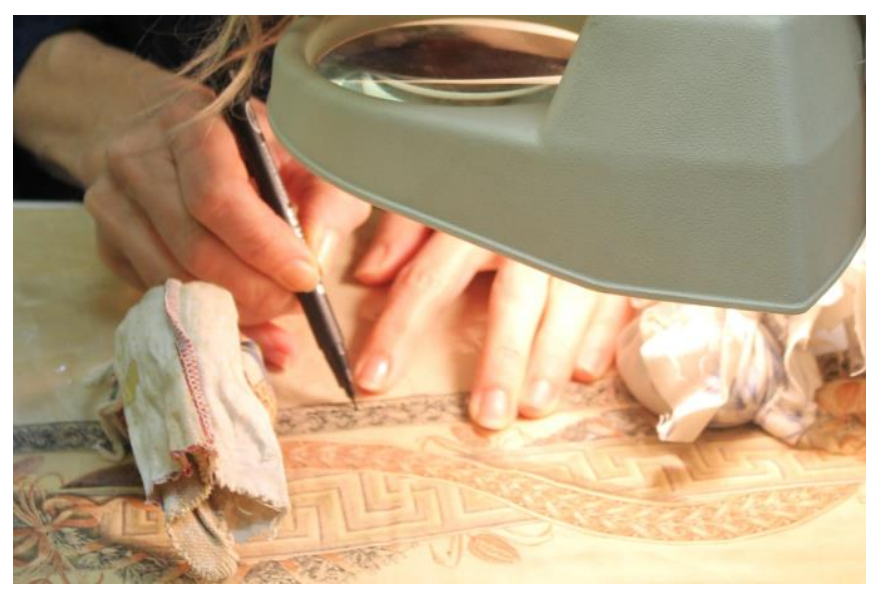

Figure A3. Reconstruction of the geometrical decoration on Melinex ${ }^{\circledR}$.

Later, we added the missing colors. During this procedure, we did not retouch the original parts but just the new areas, to maintain the originality of the artifact. A few stains and halos were further thinned out with watercolor pencils. After these phases and before the final mounting, everything was ironed at $48^{\circ} \mathrm{C}$, with the protection of an acid-free thin paper. The heated iron was used to smooth the tissue and stabilize the colors.

In the next phase, every part of the chasuble was re-attached to the original lining, locked with an under-stitching, joining the two cloths with long stiches on the inside and short stitches on the outside, using thinly woven silk thread.

Finally, all the parts of the artifact were put together using three parallel stitching techniques: "reverse thread", "under thread" and "filza", according to needs and respecting the sequences of the original stitching. Accordingly, pieces of the original threads were recuperated to carry out part of the stitching. Therefore, the lining of the "recto (front)" of the chasuble was stitched together with the silk ribbon that had been cleaned and ironed beforehand.

Both the stole and the maniple were restored while trying not to completely dismount the relative linings, sparing as much as possible of the original sewing. The same cleaning with swabs on a low-pressure table was also performed on the stole and the maniple (Figure A4). 


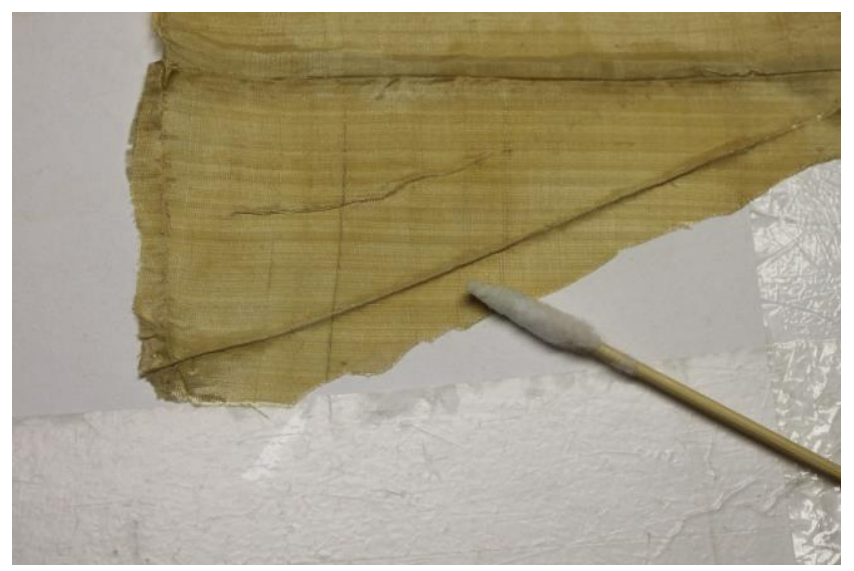

Figure A4. Cleaning procedure with a cotton swab on the verso of the stole to remove stains.

In the parts where we were obliged to intervene with inserts sown with a needle, such as areas of the cloth cut or missing, we undid parts of the linings and put little carton-plume rods between the lining and the cloth, to avoid the possibility that the stiches used to link the sustaining parts of the process would not be sown to the lining.

To connect the sustaining parts, we used the same method used for the chasuble. In the parts with defective borders, especially in the folds, the sustaining parts were fixed with "filze"; then, the borders were folded over silk sustainers and sown to the principal cloth, maintaining the original threads and stiches.

The purse was micro-aspirated and whenever possible the spots of oxidation were lightened with very small cotton pads wetted with $3 \%$ hydrofluoric acid in distilled water. In the four corners, we introduced small pads of ermesino silk sewn with thread to cover the filling cloth. To correctly deform the purse, it was placed under appropriate weights. The same procedures for spot removal and integration were made on the lining, when necessary, interposing small fragments of Lyon canvas or organza secured with thread stitching.

The chalice veil was micro-aspirated on both sides. The lining was undone only in the zones in which interventions were necessary and, in particular, close to the oxidation spots, treated with tampons imbued with 3\% hydrofluoric acid in distilled water on a portable low-pressure table, according to the type of spot to remove. On the lining, we also positioned little stands of Lyon veil under all missing parts.

The front was in better conditions and was only cleaned, treating the spots with tampons in distilled water on a low-pressure table. The lining of both artifacts was re-sewn with the original thread.

\section{References}

1. Di Lazzaro, P.; Guarneri, M.; Murra, D.; Spizzichino, V.; Danielis, A.; Mencattini, A.; Piraccini, V.; Missori, M. Noninvasive analyses of low-contrast images on ancient textiles: The case of the Shroud of Arquata. J. Cult. Herit. 2016, 17, 14-19. [CrossRef]

2. Ferreira, T.; Moreiras, H.; Manhita, A.; Tomaz, P.; Mirão, J.; Dias, C.B.; Caldeira, A.T. The Liturgical Cope of D. Teotónio of Braganza: Material Characterization of a 16th Century Pluviale. Microsc. Microanal. 2014, 21, 2-14. [CrossRef] [PubMed]

3. Amorello, D.; Barreca, S.; Bruno, M.; Milia, A.; Orecchio, S.; Pettignano, A. Chemical characterization of ancient liturgical vestment (chasuble) by Inductively Coupled Plasma-Optical Emission Spectrometry (ICP-OES). Microchem. J. 2016, 129, 305-309. [CrossRef]

4. Šimić, K.; Zamboni, I.; Fazinić, S.; Mudronja, D.; Sović, L.; Gouasmia, S.; Soljačić, I. Comparative analysis of textile metal threads from liturgical vestments and folk costumes in Croatia. Nucl. Instrum. Methods Phys. Res. Sect. B Beam Interact. Mater. At. 2018, 417, 115-120. [CrossRef]

5. Pelosi, C.; Falletta, G.; De Dominicis, B.; Baraldi, P. The Painted Silk Panels of Palazzo Barberini at Rome. The Scientific Investigation and Preservation Challenge. Procedia Chem. 2013, 8, 248-257. [CrossRef]

6. Fedi, M.; Cartocci, A.; Taccetti, F.; Mando, P.A. AMS radiocarbon dating of medieval textile relics: The frocks and the pillow of St. Francis of Assisi. Nucl. Instrum. Methods Phys. Res. Sect. B Beam Interact. Mater. At. 2008, 266, 2251-2254. [CrossRef] 
7. Witkowski, B.; Ganeczko, M.; Hryszko, H.; Stachurska, M.; Gierczak, T.; Biesaga, M. Identification of orcein and selected natural dyes in 14th and 15th century liturgical paraments with high-performance liquid chromatography coupled to the electrospray ionization tandem mass spectrometry (HPLC-ESI/MS/MS). Microchem. J. 2017, 133, 370-379. [CrossRef]

8. Theile, J.M.; Guarda, S.O.S.G.; Croquevielle, E. Analysis conservation and restoration of the metal threads used in Latin American colonial saints' robes. In Proceedings of Metal; National Museum of Australia: Canberra, Australia, 2004; pp. 501-513.

9. Muros, V.; Wärmländer, S.K.; Scott, D.A.; Theile, J.M. Characterization of 17Th-19Th Century Metal Threads from the Colonial Andes. J. Am. Inst. Conserv. 2007, 46, 229-244. [CrossRef]

10. Olaru, A.; Geba, M.; Vlad, A.M.; Ciovică, S. Metallic accessories on ethnographic textiles deterioration problems. Eur. J. Sci. Theol. 2013, 9, 177-186.

11. Edwards, H.G.M.; Farwell, D.W.; Perez, F.R.; Garcia, J.M. Mediaeval cantorals in the Valladolid Biblioteca: FT-Raman spectroscopic study. Analyst 2001, 126, 383-388. [CrossRef]

12. Lech, K. Dataset supporting the identification of natural dyes in yellow, orange, brown and green fibres from Krakow liturgical vestments. Data Brief 2020, 31, 105735. [CrossRef]

13. Thompson, K.; Smith, M.; Lennard, F. A literature review of analytical techniques for materials characterisation of painted textiles-Part 1: Categorising painted textiles, sampling and the use of optical tools. J. Inst. Conserv. 2017, 40, 64-82. [CrossRef]

14. Degano, I.; Ribechini, E.; Modugno, F.; Colombini, M.P. Analytical Methods for the Characterization of Organic Dyes in Artworks and in Historical Textiles. Appl. Spectrosc. Rev. 2009, 44, 363-410. [CrossRef]

15. Bonizzoni, L.; Bruni, S.; Fanti, G.; Tiberio, P.; Zaffino, C. Ageing of flax textiles: Fingerprints in micro-Raman spectra of single fibres. Microchem. J. 2016, 125, 69-74. [CrossRef]

16. Gulmini, M.; Idone, A.; Davit, P.; Moi, M.; Carrillo, M.; Ricci, C.; Bello, F.D.; Borla, M.; Oliva, C.; Greco, C.; et al. The "Coptic" textiles of the "Museo Egizio" in Torino (Italy): A focus on dyes through a multi-technique approach. Archaeol. Anthr. Sci. 2017, 9, 485-497. [CrossRef]

17. Gulmini, M.; Idone, A.; Diana, E.; Gastaldi, D.; Vaudan, D.; Aceto, M. Identification of dyestuffs in historical textiles: Strong and weak points of a non-invasive approach. Dye. Pigment. 2013, 98, 136-145. [CrossRef]

18. Angelini, L.G.; Tozzi, S.; Bracci, S.; Quercioli, F.; Radicati, B.; Picollo, M. Characterization of traditional dyes of the mediterranean area by non-invasive UV-VIS-NIR reflectance spectroscopy. Stud. Conserv. 2010, 55, 184-189. [CrossRef]

19. Dyer, J.; Tamburini, D.; O'Connell, E.R.; Harrison, A. A multispectral imaging approach integrated into the study of Late Antique textiles from Egypt. PLoS ONE 2018, 13, e0204699. [CrossRef] [PubMed]

20. Klisińska-Kopacz, A. Non-destructive characterization of 17th century painted silk banner by the combined use of Raman and XRF portable systems. J. Raman Spectrosc. 2015, 46, 317-321. [CrossRef]

21. Christiansen, T.; Buti, D.; Dalby, K.; Lindelof, P.E.; Ryholt, K.; Vila, A. Chemical characterization of black and red inks inscribed on ancient Egyptian papyri: The Tebtunis temple library. J. Archaeol. Sci. Rep. 2017, 14, 208-219. [CrossRef]

22. Piccolo Paci, S. Storia delle Vesti Liturgiche. Forma, Immagine e Funzione, Ancora; Still: Milano, Italy, 2008.

23. Available online: https://collections.vam.ac.uk/item/O353313/vestments-unknown (accessed on 8 March 2021).

24. Dyer, J.; Verri, G.; Cupitt, J. Multispectral Imaging in Reflectance and Photo-induced Luminescence modes: A User Manual. 2013. Available online: https:/ / www.researchgate.net/publication/267266175_Multispectral_Imaging_in_Reflectance_and_Photoinduced_Luminescence_modes_A_User_Manual (accessed on 8 March 2021).

25. Cosentino, A. Infrared Technical Photography for Art Examination. e-Preserv. Sci. 2016, 13, 1-6.

26. Shugar, A.N.; Mass, J.L. Handheld XRF for Art and Archaeology; Leuven University Press: Leuven, Belgium, 2013; ISBN 9789058679079.

27. Bezur, A.; Lee, L.; Loubser, M.; Trentelman, K. Handheld XRF in Cultural Heritage. A Practical Workbook for Conservators; J. Paul Getty Trust and Yale University: Los Angeles, CA, USA, 2020; ISBN 978-1-937433-61-1. (online resource)

28. Derrick, M.R.; Stulik, D.C.; Landry, J.M. Infrared Spectroscopy in Conservation Science. Scientific Tools for Conservation; Getty Conservation Institute: Los Angeles, CA, USA, 1999. Available online: http://hdl.handle.net/10020/gci_pubs/infrared_ spectroscopy (accessed on 8 March 2021).

29. Garside, P.; Lahlil, S.; Wyeth, P. Characterization of Historic Silk by Polarized Attenuated Total Reflectance Fourier Transform Infrared Spectroscopy for Informed Conservation. Appl. Spectrosc. 2005, 59, 1242-1247. [CrossRef] [PubMed]

30. Kavkler, K.; Gunde-Cimerman, N.; Zalar, P.; Demšar, A. FTIR spectroscopy of biodegraded historical textiles. Polym. Degrad. Stab. 2011, 96, 574-580. [CrossRef]

31. Luo, X.; Wu, J.; Intisar, A.; Geng, J.; Wu, L.; Zheng, K.; Du, Y. Study on Light Aging of Silk Fabric by Fourier Transform Infrared Spectroscopy and Principal Component Analysis. Anal. Lett. 2012, 45, 1286-1296. [CrossRef]

32. Edwards, H.G.M.; Wyeth, P. Ancient Textile Fibres. In Raman Spectroscopy in Archaeology and Art History; Edwards, H.G.M., Chalmers, J.M., Eds.; The Royal Society of Chemistry: Cambridge, UK, 2005; pp. 304-324.

33. Bell, I.M.; Clark, R.J.; Gibbs, P.J. Raman spectroscopic library of natural and synthetic pigments (pre- $\approx 1850$ AD). Spectrochim. Acta Part A Mol. Biomol. Spectrosc. 1997, 53, 2159-2179. [CrossRef]

34. Lluveras-Tenorio, A.; Bonaduce, I.; Andreotti, A.; Colombini, M.P. GC/MS Analytical Procedure for the Characterization of Glycerolipids, Natural Waxes, Terpenoid Resins, Proteinaceous and Polysaccharide Materials in the Same Paint Microsample Avoiding Interferences from Inorganic Media. Anal. Chem. 2010, 82, 376-386. [CrossRef] 
35. Tamburini, D.; Dyer, J. Fibre optic reflectance spectroscopy and multispectral imaging for the non-invasive investigation of Asian colourants in Chinese textiles from Dunhuang (7th-10th century AD). Dye. Pigment. 2019, 162, 494-511. [CrossRef]

36. Fischer, C.; Kakoulli, I. Multispectral and hyperspectral imaging technologies in conservation: Current research and potential applications. Stud. Conserv. 2006, 51, 3-16. [CrossRef]

37. Hain, M.; Bartl, J.; Jacko, V. Multispectral analysis of cultural heritage artefacts. Meas. Sci. Rev. 2003, 3, 9-12.

38. Havermans, J.; Aziz, H.A.; Scholten, H. Non Destructive Detection of Iron Gall Inks by Means of Multispectral Imaging Part 1: Development of the Detection System. Restaurator 2003, 24, 55-60. [CrossRef]

39. Havermans, J.; Aziz, H.A.; Scholten, H. Non Destructive Detection of Iron-Gall Inks by Means of Multispectral Imaging Part 2: Application on Original Objects Affected With Iron-Gall-Ink Corrosion. Restaurator 2003, 24, 88-94. [CrossRef]

40. Cosentino, A. Practical notes on ultraviolet technical photography for art examination. Conserv. Patrimoacute 2015, 21, 53-62. [CrossRef]

41. Mairinger, F. The ultraviolet and fluorescence study of paintings and manuscripts. In Radiation in Art and Archeometry; Creagh, D.C., Bradley, D.A., Eds.; Elsevier Science: Amsterdam, The Netherlands, 2000; pp. 56-75. ISBN 9780444504876.

42. Becker, M.A.; Magoshi, Y.; Sakai, T.; Tuross, N.C. Chemical and physical properties of old silk fabrics. Stud. Conserv. 1997, 42, 27-37. [CrossRef]

43. Vilaplana, F.; Nilsson, J.; Sommer, D.V.P.; Karlsson, S. Analytical markers for silk degradation: Comparing historic silk and silk artificially aged in different environments. Anal. Bioanal. Chem. 2014, 407, 1433-1449. [CrossRef]

44. Winter, J. The characterization of pigments based on carbon. Stud. Conserv. 1983, 28, 49-66. [CrossRef]

45. Hinrichs, R.; Vasconcellos, M.A.Z.; Österle, W.; Prietzel, C. Amorphization of Graphite Flakes in Gray Cast Iron under Tribological Load. Mater. Res. 2018, 21, e2017100. [CrossRef]

46. Froment, F.; Tournié, A.; Colomban, P. Raman identification of natural red to yellow pigments: Ochre and iron-containing ores. J. Raman Spectrosc. 2008, 39, 560-568. [CrossRef]

47. Tomasini, E.P.; Halac, E.B.; Reinoso, M.; Di Liscia, E.J.; Maier, M.S. Micro-Raman spectroscopy of carbon-based black pigments. J. Raman Spectrosc. 2012, 43, 1671-1675. [CrossRef]

48. Ferrari, A.C.; Robertson, J. Interpretation of Raman spectra of disordered and amorphous carbon. Phys. Rev. B 2000, 61, 14095-14107. [CrossRef]

49. Goler, S.; Hagadorn, A.; Ratzan, D.M.; Bagnall, R.; Cacciola, A.; McInerney, J.; Yardley, J.T. Using Raman spectroscopy to estimate the dates of carbon-based inks from Ancient Egypt. J. Cult. Herit. 2019, 38, 106-117. [CrossRef]

50. Goler, S.; Yardley, J.T.; Cacciola, A.; Hagadorn, A.; Ratzan, D.; Bagnall, R. Characterizing the age of ancient Egyptian manuscripts through micro-Raman spectroscopy. J. Raman Spectrosc. 2016, 47, 1185-1193. [CrossRef]

51. Lluveras-Tenorio, A.; Mazurek, J.; Restivo, A.; Colombini, M.P.; Bonaduce, I. Analysis of plant gums and saccharide materials in paint samples: Comparison of GC-MS analytical procedures and databases. Chem. Cent. J. 2012, 6, 115. [CrossRef] [PubMed]

52. Bonaduce, I.; Ribechini, E.; Modugno, F.; Colombini, M.P. Analytical Approaches Based on Gas Chromatography Mass Spectrometry (GC/MS) to Study Organic Materials in Artworks and Archaeological Objects. Top. Curr. Chem. 2016, 374, 1-37. [CrossRef] [PubMed]

53. Beyeler, C. Les ambiguïtés du Salon à Paris: Romains aux Tuileries et Français à Saint-Pierre. In Pie VII Face à Napoléon. La Tiare dans les Serres de l'Aigle; Beyeler, C., Hebert, J.F., Droguet, V., Eds.; RMN: Paris, France, 2015; pp. 147-153, ISBN 10271186247X.

54. Beyeler, C. Rome-Paris-Fontainebleau, 1796-1814, direction scientifique du catalogue et rédaction de deux essais: Concurrence entre Rome et Paris. Mises en image rivales du Concordat. In Pie VII Face à Napoléon. La Tiare dans les Serres de l'Aigle; Beyeler, C., Hebert, J.F., Droguet, V., Eds.; RMN: Paris, France, 2015; pp. 53-57, ISBN 10271186247X.

55. Del Prete, R. Piccole Tessitrici Operose. Gli Orfanotrofi Femminili a Benevento; Franco Angeli: Milano, Italy, 2010; p. 108, ISBN 978-8856832082. 